\title{
Türkiye'deki Bölgelerin Lojistik Köy Kurulması Açısından Potansiyelinin PROMETHEE II Yöntemi ile İncelenmesi
}

\section{Investigating the Potential of the Regions in Turkey for the Establishment of a Logistics Village using the PROMETHEE II Method}

\author{
Yeliz DEMİRKIRAN, Yaşar Üniversitesi, Türkiye, yeliz.kocaman@yasar.edu.tr \\ Orcid No: 0000-0003-3998-7001 \\ Ömer ÖZTÜRKOĞLU, Yaşar Üniversitesi, Türkiye, omer.ozturkoglu@yasar.edu.tr \\ Orcid No: 0000-0003-3937-6657
}

\begin{abstract}
Öz: Küreselleşme ile beraber artan ticaret hacmi dünyada mal dolaşımın ve dolaylst ile lojistik faaliyetleri artırmaktadır. Bu lojistik faaliyetlerin yüksek verimlilikle gerçekleşmesinde lojistik firmalarının, depoların, aktarma merkezlerinin, gümrük firmalarının bir arada konumlandığı lojistik köyler büyük önem taşımaktadır. Lojistik köyler şehir içindeki trafik yoğunluğunu azaltmak, kombine taşımacllı̆̆ teşvik etmek, farklı taşıma modlarının bağlantılarına olanak sağlamak gibi amaçlarla kurulmaktadır. Neticede lojistik maliyetlerin düşürülmesine olanak sağlamakta ve şiddetli rekabet ortamında ișletmelere daha kisa sürede ihtiyaçlarına ulaşabilme imkânı sunmaktadırlar. Lojistik köy kurmada en önemli karar yer seçimidir. Çalışmanın amacı tüm illerini kapsayacak şekilde Türkiye'nin lojistik köy potansiyelini ortaya çılkarmak ve araştırmacılara elde edilen bilgiler ışığında stratejik bir yol haritası sunmaktır. Yer seçimi kararını etkileyen 4 kriter nitelikli işgücü, ulaşım altyapısı, ekonomik ve kalkınma ş̧eklinde belirlenmiştir. Bu 4 kriter altında 16 alt kriter ayrlca belirlenmis, her birinin kriter ağırlikları 24 farklı senaryo seklinde düzenlenmiștir. Calıșmada lojistik köy yer seçimi için Türkiye'deki 81 ili kapsayan 26 (TÜIK-Düzey2) bölge belirlenen kriterler açısından nicel veriler kullanılarak değerlendirilmişstir. Değerlendirmede çok kriterli karar verme yöntemlerinden PROMETHEE II kullanılmıștır. Bütün senaryolarda İstanbul potansiyeli en yüksek bölge olarak çıkmıştır. Sonraki analizlerde nitelikli işgücü, ulaşım altyapısı ve ekonomik kriterlerin önemli olduğu senaryolarda içinde İzmir, Ankara ve İzmit' in bulunduğu TR31, TR32, TR,41, TR42, TR51 ve TR90 bölgeleri potansiyeli en yüksek bölgeler olarak tespit edilmiştir. Kalkinma kriterinin önemli olduğu senaryolarda ise Kars, Tatvan'ı içine alan sırasıyla TRA2, TRB2, TRB1, TRC1 ve TRC2 bölgeleri ön plana çımıştır.
\end{abstract}

Anahtar Kelimeler: Lojistik köy, Yer Seçimi, Çok kriterli karar verme, Promethee JEL Sinfflandirmast: R53, L90, C02

\begin{abstract}
The increasing volume of trade due to globalization increases the circulation of goods in the world and hence the logistics activities. In order to realize these logistic activities with high efficiency, logistic villages that includes warehouses, transfer centers and customs firms are very important. Logistics villages are established to reduce the traffic density in the city, to promote combined transport, and to enable the connection of different modes of transport. As a result, they enable logistic costs to be reduced and provide enterprises the opportunity to reach their needs in a shorter time in a fierce competition environment. The most important decision in establishing a logistic village is location selection. The aim of the study is to present the potential of provinces in Turkey with respect to the establishment of logistics villages and to present a strategic road map to the researchers in the light of the information obtained. The 4 criteria affecting the decision on location selection were determined as qualified labor, transportation infrastructure, economic and social benefit. Under these 4 criteria, 16 sub-criteria were also determined, and the criteria weights of each were arranged under 24 different scenarios. For site selection of logistics village, in 26 regions of Turkey (TSI-Level2) that includes 81 provinces were evaluated with quantitative data under determined criteria. Evaluation is done using with PROMETHEE II method. As a result, Istanbul is the most appropriate region for logistics village establishmet. Besides that in scenarios where qualified labor, transportation infrastructure and economic criteria are important, TR31, TR32, TR,41, TR42, TR51 and TR90 regions that include İzmir, Ankara and İzmit have the highest potential for logistics village establishment. In the scenarios where development crteria is important, TRA2, TRB2, TRB1, TRC1 and TRC2 regions that include Kars and Tatvan have emerged in the top 5 rank.
\end{abstract}

Keywords: Logistics Village, Location Selection, Multiple criteria decision making, Promethee JEL Classification: R53, L90, C02

\section{Giriş}

Lojistik köyler tanım gereği lojistik ve malların dağıtımı ile ilgili olarak bütün ilgili faaliyetlerin bir arada bulunduğu ve çeşitli taşıma modlarının birbiriyle bağlantılı olarak taşıma altyapısının sunulduğu coğrafi alanları temsil etmektedir (Europlatforms, 2015). Önden vd. (2015) lojistik merkezleri tüm lojistik operasyonlarının tek veya belirli noktalarda sağlanmış olduğu, ölçeğine göre yerel veya küresel olabilen tesisler şeklinde tanımlamışlardır. Rimiene ve Grundey (2007) lojistik merkezleri yük hareketinde yer alan tüm faaliyetleri en iyi şekilde yönetmek için planlanmış ve inşa edilmiş bir köy olarak tanımlamış ve büyük ölçekli lojistik merkezleri lojistik köy olarak tanımlamıştır. Ayrıca Higgins vd. (2012) dağıtım merkezi, yük köyü, endüstriyel park, lojistik merkez ve transfer terminali gibi kavramların da lojistik köyü temsil ettiklerini belirtmiş̧lerdir. Lojistik köylerin bölge ekonomisine, ticaretine ve hatta çevreye olan etkisi ile ilgili olarak Yang et al. (2015) lojistik köylerin Avrupa'da iş hacmini artırıcı etkisi olduğunu belirtmiştir. Ayrıca, Bodaubayeva (2015) lojistik köylerin bölgenin büyümesine olumlu, rekabet avantajını artırıcı ve maliyeti azaltıcı etkileri olduğunu göstermiştir. Calis and Gencer (2014) ise lojistik köylerin sadece lojistik maliyetlerini düşürücü etkisinin olmadığını

Makale Gecmiși / Article History

Başvuru Tarihi / Date of Application Kabul Tarihi / Acceptance Date
: 6 Eylül / September 2019

: 20 Ocak / January 2020 
ayrıca lojistik hizmetlerin kalitesini artırıcı etkisi ile birlikte lojistik faaliyetlerden kaynaklanan karbon emisyonunu azaltıcı etkisi olduğunu da belirtmiştir. Bu etkilerinden dolayı son 10 yılda gelişen ekonominin de katkısı ile Türkiye'de lojistik köylerin kurulumu ile ilgili çalışmalar artış göstermiş, bir çok bölgede lojistik köy kurulmuş veya kurulması planlanmıştır. 2019 Türkiye Lojistik Master Planında da Türkiye'de yeni lojistik köylerin veya üslerin kurulmasının önemi vurgulanmış ve bu konuda planlamaların olduğu belirtilmiştir (TLMP Yönetici özeti, 2019). Ayrıca, 2013 yılında Çin Halk Cumhuriyeti "Bir Kuşak Bir Yol” projesi kapsamında Avrupa pazarına hem kara hem de deniz yolları ile etkin bir şekilde ulaşmak için bu coğrafyada jeopolitik öneme sahip olan Türkiye'de lojistik alanında yatırımlar yapmaya başlamış ve faaliyetlerini yoğunlaştırmak için bazı bölgelerde araştırma içerisinde olduklarını belirtmişlerdir (Artan vd., 2018). Bu konu ile ilgili olarak 2019 yılının Ekim ayında Çin'den çıkan bir konteyner treni ilk kez Bakü-Tiflis üzerinden Türkiye Cumhuriyeti Devlet Demiryolları (TCDD) hatlarını ve Marmarayı kullanarak Avrupa'ya mal göndermiştir (Habertürk, 2019). Hem kuşak-yol projesi hem de Türkiye'nin sahip olduğu jeostratejik ve jeopolitik özellikleri, Türkiye'nin içinde bulunduğu bölgede önemli bir lojistik üs olma potansiyelini ve devletin bu konudaki vizyonunu desteklemektedir.

Böylece bu çalışma Türkiye'de lojistik köy veya üs yer seçimi problemini ele almaktadır. Bölüm 1.2'de sunulmuş lojistik köy yer seçimi problemi ile ilgili literatürdeki çalışmalar incelendiğinde aşağıdaki 3 konuda eksikler tespit edilmiştir.

1. Stratejik olarak Türkiye'nin bütün illerinin lojistik köy kurabilme potansiyelini gösteren bir çalışma bulunmamaktadır. Bütün çalışmalar kısıtlı bölgelerde yapılmıştır.

2. Analizlerde çoğunlukla nitel veri ve değerlendirmeler ele alındığı için ortaya konulan sonuçlar karar vericilere net bir yol haritası sunmamaktadır. Ayrıca çalışmalarda duyarlılık analizi çoğunlukla yapılmamıştır.

3. Çalışmalarda ağırlıklı olarak ekonomik, ulaşım ve ticaret potansiyeli dikkate alınırken bölgesel farklılıkların azaltılması ve sürdürülebilirlik açısından kalkınma perspektifi çoğu zaman ihmal edilmiştir.

Böylece bu çalışma literatürdeki bu boşlukları doldurmayı ve özellikle Türkiye'deki karar vericilere Türkiye'nin lojistik köy yer seçimi açısından potansiyelini ortaya koymayı hedeflemektedir. Bu yazının bir sonraki alt bölümlerinde Türkiye'de lojistik köylerin gelişimi dünyadaki örnekler ile kısaca karşılaştırmalı olarak sunulup lojistik köy yer seçiminde yapılmış, özelliklede Türkiye'yi esas alan çalışmalar detaylı olarak incelenmiştir. Takip eden bir sonraki bölümde benimsenen araştırma metodolojisinde ele alınan kriterler, seçilen çok kriterli karar verme tekniği, veri kaynakları ve kriter ağırlıkları detaylı olarak anlatılmıştır. Son olarak, araştırmanın sonuçları detaylı olarak incelenmiş ve karar vericilere yardımcı olacak şekilde literatürdeki benzer çalışmalar ve mevcut uygulamalar da dikkate alınarak tartışılmıştır.

\subsection{Türkiye'de Lojistik Faaliyetler ve Köylerin Gelişimi}

21. asrın başından bu yana gelişen küresel ekonomi aralarında Türkiye'nin de olduğu gelişmekte olan ülkelerin hem dış ticaret hem de ekonomik faaliyetlerini geliştirmiştir. Türkiye İstatistik Kurumu (TÜIK)'nun verileri esas alındığında, 2000 yılından bu yana Amerikan doları bazında Türkiye’nin Gayri Safi Yurtiçi Hasılası (GSYH)'nın yaklaşık iki kat, dış ticaret hacminin de yaklaşık 4 kat büyüdüğü görülmektedir (TÜIK, 2019; T.C. Ticaret Bakanlığı, 2019). Türkiye'nin hem büyüyen iç ve dış ticareti hem de jeostratejik özelliğii, Türkiye'de mal ve hizmetlerin dolaşımını esas alan lojistik faaliyetlerin hızla gelişmesini etkilemiştir. Lojistik faaliyetlerin etkin bir şekilde yerine getirilebilmesi açısından, lojistik altyapıyı güçlendirmek için karayolları, demiryolları, havayolları, limanlar alanında büyük altyapı çalışmaları (Marmaray, Osman Gazi Köprüsü, İstanbul Yavuz Sultan Selim Köprüsü, Doğu Anadolu bölgesi ile Karadeniz bölgesini birbirine bağlayan tüneller, Bakü-Tiflis demiryolu, İstanbul Havalimanı, vb.) ve projeleri hayata geçirilmiş ve birçoğu tamamlanmıştır. Bu gelişmelerden dolayı birçok uluslararası lojistik firması da Türkiye'de faaliyetlerini artırmaktadır. Hem mevcut hem de yeni kurulan lojistik şirketleri ile lojistik sektörü büyük bir ivme ile gelişme göstermektedir. Böylece, bu gelişmeler, farklı lojistik faaliyetlerin ve hizmetlerin bir bölge içerisinde sunularak lojistik faaliyetlerin etkinliğini artırmayı hedeflemektedir. Bu nedenlerle uzun yıllardır özellikle gelişmiş ve gelişmekte olan ülkelerde lojistik köylerin hem sayıca hem de fonksiyonel olarak geliştiğini görmekteyiz.

Avrupa'da pek çok Lojistik köy "Europlatforms” adındaki Lojistik köyler birliği ile birbiri ile iletişim halindedir. Avrupa'da lojistik köyler açısından yoğun faaliyet gösteren ülkelerin başında Almanya (35), İspanya (33), Fransa (26), İtalya (21) gelmektedir (Europlatform Corporate Presentation, 2015). Bu lojistik köyler arasinda Almanya'da bulunan Bremen lojistik köyü yıllık 90 bin TEU mal elleçlemesiyle en aktif lojistik köydür (Terzi ve Bölükbaş, 2016). Rungis (Sogaris) Lojistik köyü Fransa'nın, Bologna Lojistik köyü İtalya'nın ve Plaza Lojistik köyü İspanya'nın en önemli lojistik köyleridir. Oláh vd. (2018) Avrupa'da bulunan 70 adet lojistik köyü yapısal, yönetsel ve taşıma modları açısından kıyaslamışlar ve en iyi 10 lojistik köyün Almanya, İtalya ve İspanya'da olduğunu belirtmişlerdir. Ayrıca, Asya kıtasında Shenzhen Pinghu Logistics, Huaihai Integrated Logistics Park ve Shanghai North-West ILP Çin Halk Cumhuriyeti'nin; Busan New Port Distripark ve Gwangyang Port Distripark Güney Kore'nin; Far Glory FTZ de Tayvan'ın önemli lojistik merkezleri arasındadır. Amerika Birleşik Devletlerinde ise AllianceTexas, Global TransPark, Greater Columbus Inland Port/Rickenbacker Intermodal Facility, Pureland Industrial Complex önemli lojistik merkezleri arasında yer almaktadır 
(Baydar vd., 2017). Önemli örneklerini Avrupa, Asya ve Kuzey Amerika‘da gördüğümüz lojistik köylerin gelişimi Türkiye'de de lojistik köylerin kurulmasını tetikleyen unsurlar arasındadır.

Türkiye'de lojistik köylerin pek çoğu Türkiye Cumhuriyeti Devlet Demiryolları (TCDD) tarafından kurulmakta ve yönetilmektedir. Samsun (Gelemen), Uşak, İstanbul (Halkalı), Eskişehir (Hasanbey), Denizli (Kalkık), İzmit (Köseköy), Balıkesir (Gökköy) lojistik köyleri aktif olarak faaliyet gösteren, Bilecik (Bozüyük), Mardin, Erzurum (Palandöken), Mersin (Yenice), Kahramanmaraş (Türkoğlu) ise yapımı devam eden lojistik köyleridir. Yapımı Altyapı yatırımları genel müdürlüğü'ne (AYGM) ait olan İzmir (Kemalpaşa) lojistik köyü tamamlandığında $3.000 .000 \mathrm{~m}^{2}$ lik kapasitesi ile Türkiye'nin en büyük lojistik köyü haline gelecektir. 1538 adet çalı̧̧an ile yılda 16 milyon ton yük elleçlenmesi hedeflenmektedir (TCDD, 2019). Planlanan tüm lojistik köyler tamamlandığında Türk lojistik sektörüne 35,6 milyon ton ilave taşıma imkânı, 40 milyar dolarlık katkı ve 10 bin kişiye istihdam sağlaması hedeflenmiştir (Baki, 2018). Ayrıca, İstanbul Büyükşehir Belediyesi tarafından yapılan Hadımköy Lojistik Köyü ve Kamu-özel sektör ortak girişimi projesi olan ve Manisa Lojistik Köyü (MOSBAR) de faaliyetlerini sürdürmektedirler.

Türkiye'nin ilk lojistik köyü Samsun (Gelemen) lojistik köyü bölgenin önemli bir liman kenti olmasından ve denizyolu, karayolu sistemlerine sahip, önemli bir kavşak noktası olmasından yararlanılarak bu bölgede kurulmuştur (Baki, 2018). Demir, hurda, rulo saç, bakır, klinker, konteyner, çimento, kömür, kereste, buğday, gıda maddesi, un ve gübre gibi ürünlerin taşındığı lojistik köyde demiryolu taşıma kapasitesinin 1.100 .000 tona çıkması hedeflenmiştir (Karadeniz ve Akpınar, 2011). Balıkesir (Gökköy) projesi Tekirdağ-Bandırma arasında yer alacak olan Tren-Feri projesi ve Bakü-Kars-Tiflis demiryolu projesi ile entegre şekilde tasarlanmıştır. Balıkesir bölgesinin bu proje ile Avrupa-Asya hattında önemli bir rol üstlenmesi planlanmıştır (Baki, 2018). Otomobil, konteyner, sunta, mermer, gıda maddeleri, kaolin, elyaf ve sentetik malzeme, kömür, askerî malzeme ve demir cevheri gibi çeşitli ürünlerin taşındığı Balıkesir (Gökköy) lojistik köyünde yük miktarının 1.000 .000 tona ulaşması hedeflenmiştir (Karadeniz ve Akpınar, 2011). DenizliKaklık lojistik köyü bölgenin tekstil ihracatındaki başarısı dikkate alınarak kurulmuştur. Eskişehir (Hasanbey), lojistik köyünün kurulmasında bölgenin karayolu ve demiryolu üstünlükleri kullanılmıştır ayrıca bölgenin başkent Ankara'ya da yakın olması Lojistik merkez olması açısından avantajlı olmuştur (Baki, 2018). Proje sayesinde gelişen demiryolu taşıma olanakları ile çoğunlukla fayans, feldispat, demir, seramik, inşaat malzemeleri, beyaz eşya, konteyner, manyezit, gıda maddesi, su ve kömür nakliyesi yapılmaktadır (Karadeniz ve Akpınar, 2011). İstanbul (Halkalı) lojistik köyünün kurulmasında karayolu ve demiryolu ile taşınan uluslararası yüklerin pek çoğunun TCDD Halkalı tesislerinden ve gümrüğünden geçmesinden dolayı bölge tercih edilmiştir (Baki, 2018). Yıllık taşıma kapasitesi 2.000.000 ton olan Halkalı Lojistik köyü diğerlerinden farklı olarak RO-LA taşımacılığına olanak sağlamaktadır (Karadeniz ve Akpınar, 2011). İzmit (Köseköy) lojistik köyünün ağır sanayi tesisleri ve liman işletmeleri ile Marmara bölgesinin tamamına hizmet vermesi ve dış ticarete yönelik ulaştırma faaliyetlerinin organize edilmesi için bölgede kurulması planlanmıştır (Baki, 2018). Yıllık taşıma kapasitesinin 1.500 .000 ton olması planlanan lojistik köyde ağırlıklı olarak otomobil, otomotiv yedek parçası, sunta, petrol ürünleri, alçıtaşı, konteyner, klinker, demir, selüloz, emaye hammaddesi, su, borasit ve çelik sac gibi ürünlerin taşınmaktadır (Karadeniz ve Akpınar, 2011). Uşak bölgesinde seramik, konteyner, battaniye, iplik, mermer, plastik hammaddesi, makine ekipmanları ve gıda malzemelerinin taşımasında demiryolu tercih edilmesi ve bölgedeki demiryolu altyapısının geliştirmek amacıyla Uşak Lojistik köyü kurulmuştur (Baki, 2018). İzmir ile Manisa arasındaki 65 km’lik mesafede günde 400 kamyon ve TIR ile yük taşınmaktadır. MOSBAR Lojistik köyünün demiryolu bağlantısı sayesinde karayolu taşımacılı̆̆ \% 40 oranında düşmektedir (Karadeniz ve Akpınar, 2011).

Türkiye'deki lojistik çalışmaların son yıllarda artış göstermesine rağmen, Dünya Bankası'nın ülkeler bazında her iki yılda bir hesapladığı Lojistik Performans İndeks (LPİ) değerine göre Türkiye 2016 yılında 3,42 puanla 34. sırada yer alırken 2018 yılında 3,15 puanla 47. Sırada yer almıştır. 2018 LPİ sıralamasında birinciliğin Almanya'da ve ilk 10 ülkenin 8'inin Avrupa'da yer aldığı görülmektedir (Dünya Bankası, 2019). LPİ'nin temel aldığı kriterler incelendiğinde, Avrupa'daki lojistik köylerin Avrupa ülkelerinin LPİ değerine katkısının önemli olduğu söylenebilir. Bu kriterler: (1) gümrük işlemlerindeki etkinlik, (2) ticaret ve taşımacılık ile ilgili altyapının kalitesi, (3) uluslararası sevkiyatların kolaylı̆̆ , (4) lojistik faaliyetlerin kalitesi ve personelin yetkinliği, (5) yüklerin izlenebilirliği ve (6) sevkiyatların zamanında elleçlenmesi ve teslimatıdır (The World Bank, 2018). Avrupa ülkeleri ile Türkiye'nin LPİ sıralamasında büyük fark olmasının nedenlerinden bazılarının Avrupa'daki lojistik köylerin Türkiye'dekilere göre toplam alan, intermodal taşımacılığa elverişlilik, uluslararası yol bağlantılarına sahiplik, çalışan sayısı, altyapı, taşınan yük miktarı, liman ve havalimanı entegrasyonu gibi lojistik ile ilgili temel faaliyetlerin etkin olmasının yanısıra banka, telekomünikasyon ve destek hizmetlerinin de etkin bir şekilde verilmesidir (Terzi ve Bölükbaş, 2016). Bu karşılaştırmalar göstermektedir ki hem LPİ kriterlerinde iyileşmelerle indeks sıralamasında daha yukarılarda yer alabilmek hem de ekonomik ve ticari gelişmeleri desteklemek için Türkiye'de yeni lojistik köy ve üslerin kurulması ve bu merkezlerin etkin bir şekilde yönetilmesi üzerinde önemle durulması gereken stratejik bir konudur. Bu konunun ilk ve en önemli aşaması da kurulması planlanan lojistik köy ve üslerin yerlerinin belirlenmesidir.

\subsection{Literatür}

Lojistik köylerin yerinin belirlenmesine yönelik çizilecek stratejik yol haritasının ilk kısmını yer seçimini etkileyen kriterlerin belirlenmesi oluşturmaktadır. Bu konu ile ilgili literatür incelendiğinde her çalışmada çok çeşitli seçim kriterleri kullanıldığı görülmektedir. Lojistik köy yer seçimi ile ilgili daha önce yapılmış çalışmalarda ele alınan kriterler yakın bir zamanda yayınlanan Uyanık vd. (2018) çalışmasıyla sunulmuştur. Bu çalışmaya göre, literatürde dikkate alınan kriterler 
beş ana kategori altında toplanmaktadır: konum, maliyet, çevre, taşıma kapasitesi ve sosyal kriterler. Aynı çalışma, alt kriterler içinde karayoluna, demiryoluna, havaalanına ve limana yakınlığın, arazi büyüklüğünün, genişleme olanağının, organize sanayi bölgelerine yakınlığın, şehir merkezine yakınlığın, makro-ekonomik faydanın, işgücü bulunabilirliğinin, arazi maliyetinin, yatırım maliyetinin, doğal kaynakların varlığının, konumun ve uluslararası ticaretin varlığının literatürde ön plana çıktığını belirtmiştir. Ayrıca, Uyanık vd. (2018)'ne göre havaalanı sayısı, gümrüğe yakınlık, liman derinliği, liman ardı bölge (hinterland) genişliği, elleçleme maliyeti, elleçleme kapasitesi, depo sayısı, iç su yollarına yakınlık, kalkınma gibi alt kriterler literatürde çok nadirde olsa kullanılmıştır.

Uyanık vd. (2018), geçmiş çalışmalarda lojistik köy yer seçimi probleminin çözümünde kullanılan yöntemleri de özetlemiştir. Buna göre, problemin çok kriterleri yapısından dolayı literatürdeki çalışmalarda çoğunlukla Çok Kriterli Karar Verme teknikleri kullanılmştır. En sık kullanılan yöntemler Analitik Hiyerarşi Proses (AHP) (Arıkan, 2013; Can, 2012; Demiroğlu ve Eleren, 2014; Eryürük vd., 2011; Görgülü, 2012; Regmi ve Hanaoka, 2013; Stevic vd., 2015; Tanyaş ve Bamyacı, 2009; Tomić vd., 2014; Yıldırım ve Önder, 2014; Önder ve Yıldırım, 2014), ELECTRE, (Can, 2012; Cristea ve Cristea, 2016; Fagaraşan ve Cristea, 2015; Ghoseiri ve Lessan, 2008; Uysal ve Yavuz, 2014; Zak ve Weglinski, 2014;), Bulanık-AHP (Chen ve Lili, 2006; Ghoseiri ve Lessan, 2008; Kayıkç1, 2010; Önden vd., 2018; Wang ve Liu, 2007) ve TOPSİS yöntemleridir (Can, 2012; Chen vd., 2014; Li vd., 2011; Özceylan vd., 2016; Wang ve Liu, 2007;). Bu çalışmalardan bazılarında veriler nitel olarak belirlenmişken (Küçük vd., 2017; Atalay vd., 2017; Önden vd., 2018) bazılarında ise nicel veriler kullanılmıştır (Demiroğlu ve Eleren, 2014; Elgün ve Aşıkoğlu, 2016; Yıldırım ve Önder, 2014; Önder ve Yıldırım, 2014). Detaylı bilgi için Uyanık vd. (2018)'nin çalışmasının incelenmesi tavsiye edilmektedir.

Türkiye ile ilgili yapılan çalışmalara baktığımızda ağırlıklı olarak nitel veri kullanıldığı gözlemlenmiştir (Atalay vd., 2017; Küçük vd., 2017; Önden vd., 2018). Nicel analiz yapılan çalışmalara az rastlanmıştır. Ayrıca bu çalışmalarda (Karadeniz ve Akpınar, 2011; Atalay vd., 2017; Küçük vd., 2017; Özceylan vd., 2016; Uysal ve Yavuz, 2014; Yıldırım ve Önder, 2014), ya sadece bir şehir, ya da bir bölge içindeki belirlenmiş şehirler karşılaştırılırken çok az çalışmada Türkiye geneli ele alınmıştır. Örneğin Demiroğlu ve Eleren (2014) çalışmasında Türkiye genelini ele almıştır ancak sadece limanların bulunduğu Bandırma, Haydarpaşa, İskenderun, İzmir, İzmit, Mersin, Samsun olmak üzere 6 liman bölgesi lojistik köy açısından değerlendirilmiştir. Değerlendirme kriterleri olarak rihtım uzunluğu, liman alanı, derinlik, serbest bölge büyüklüğü, gemi kabul kapasitesi, elleçleme kapasitesi, konteyner rıhtım ekipman kapasitesi, stoklama kapasitesi, elleçlenen yük ve konteyner miktarı, serbest bölge ihracat miktarı, serbest bölge firma sayısı, limanın bulunduğu teşvik bölgesi, il nüfusu, nüfus yoğunluğu, serbest bölgeye yakınlık, havaalanına yakınlık kriterleri kullanılmış ve sonuç olarak lojistik köy potansiyeli açısından en uygun 3 limanın Mersin, İzmir ve Haydarpaşa limanı olduğu tespit edilmiştir. Hamzaçebi vd. (2016) çalışmasında sadece Karadeniz bölgesinde yer alan 18 şehri nüfus, ithalat, ihracat, havayolu, demiryolu, malzeme elleçleme, km başına araç ve yük miktarı, şehirler arasındaki toplam mesafe ve endüstriyel enerji tüketimi kriterleri açısından değerlendirmiştir. Sonuç olarak lojistik köy için en uygun 3 bölgenin sırasıyla Samsun, Trabzon ve Zonguldak olduğu tespit edilmiştir. Elgün ve Aşıkoğlu (2016) çalışmasında Bursa, Bilecik, Eskişehir, Afyon, Kütahya, Konya ve Mersin olmak üzere 7 şehri değerlendirmiştir. Değerlendirme kriterleri olarak ulaşım, iş aktiviteleri, arazi özellikleri, yerin uygunluğu şeklinde 4 ana kriter altında 22 alt kriter kullanmışlardır ve çalışmanın sonucunda lojistik köy potansiyeli açısından en uygun ilk üç şehri Mersin, Konya ve Bilecik olarak önermişlerdir. Önder ve Yıldırım (2014) çalışmasında Türkiye'de halihazırda bir lojistik köye ya da lojistik köy projesine sahip 11 şehri değerlendirmiştir. Değerlendirme arazi büyüklüğü, arazi maliyeti, organize sanayi bölgesine (OSB) yakınlık, havaalanı, liman, demiryolu ve karayolu bağlantılarına yakınlık, ekonomiye etki şeklinde 8 kriter kullanılarak yapılmıştır. Çalışmanın sonucunda Samsun, Eskişehir, İzmit alternatifler arasından en iyi 3 bölge olarak önerilmiştir. Yangınlar (2019) çalışmasında İstanbul (Halkalı), İzmit (Köseköy), Samsun (Gelemen), Balıkesir (Gökköy), Uşak (Uşak), Denizli (Kaklık), Eskişehir (Hasanbey) illerinde halihazırda faaliyet gösteren lojistik köyleri 2009-2018 yılları arasındaki ithalat ihracat değerlerini ele alarak değerlendirmiştir, sonuç olarak Eskişehir, Balıkesir, Uşak ve Denizli illerindeki lojistik köylerin bulundukları illerin dış ticaret gelirlerine önemli ölçüde katkı sağladıklarını belirtmiştir. Tablo 1'de Türkiye kapsamında lojistik köy yer seçimi problemini ele alan çalışmaların isimleri, kaynakları, yöntemleri ve elde edilen sonuçları detaylıca gösterilmiştir.

\section{Metodoloji}

Çalışmanın bu bölümünde literatürde görüldüğü ifade edilen boşlukların giderilmesi için ele alınan yöntem detaylı bir şekilde sunulacaktır. Buna göre, ilk olarak Türkiye'nin bütününü ele alabilmek için benimsenen kümeler anlatılacaktır. İkinci olarak, çalışmamızda kullanılan ve lojistik köy veya üs yer seçim kararını etkileyen nicel kriterlerin neler olduğu ve nasıl belirlendiği açıklanacaktır. Son olarak, problemin çok kriterli yapısını etkin bir şekilde ele alan ve çok kriterli karar verme (ÇKKV) tekniklerinden olan PROMETHEE II yöntemi anlatılacaktır. 
Tablo 1. Literatür Tablosu

\begin{tabular}{|c|c|c|c|c|c|c|}
\hline Kaynak & Çalışmanın adl & $\begin{array}{l}\text { Ana kriter } \\
\text { saylst }\end{array}$ & $\begin{array}{l}\text { Alt kriter } \\
\text { Saylst }\end{array}$ & Yöntem & Kapsam & Sonuç \\
\hline Küçük vd. (2017) & $\begin{array}{l}\text { Lojistik köy performans faktörlerinin } \\
\text { önem düzeyinin belirlenmesi: } \\
\text { Kastamonu örneği }\end{array}$ & 19 & - & $\begin{array}{l}\text { Yargısal örnekleme } \\
\text { ile yüzyüze anket }\end{array}$ & Kastamonu & $\begin{array}{l}\text { Kent merkezine erişim uygunluğu en önemli kriter olarak } \\
\text { belirlenmiş ve Kastamonu ili bu kriter açısından yeterli çıkmıştır. }\end{array}$ \\
\hline $\begin{array}{l}\text { Karadeniz ve Akpınar } \\
\text { (2011) }\end{array}$ & $\begin{array}{l}\text { Türkiye'de lojistik köy uygulamaları ve } \\
\text { yeni bir lojistik köy önerisi }\end{array}$ & - & - & - & Trabzon & $\begin{array}{l}\text { Kıyı şeridinin geniş olması ve demiryolu bağlantılarının } \\
\text { genişleyecek olması Trabzon'nun iyi bir lojistik köy potansiyeli } \\
\text { olduğunu göstermektedir. }\end{array}$ \\
\hline $\begin{array}{l}\text { Elgün ve Aşıkoğlu } \\
\text { (2016) }\end{array}$ & $\begin{array}{l}\text { Lojistik köy kuruluş yeri seçiminde } \\
\text { TOPSí yöntemiyle merkezlerin } \\
\text { değerlendirilmesi }\end{array}$ & 4 & 22 & Topsis & $\begin{array}{l}\text { Bursa, Bilecik, Eskişehir, Afyon, Kütahya, } \\
\text { Konya ve Mersin }\end{array}$ & $\begin{array}{l}\text { Lojistik köy için en uygun } 3 \text { bölgenin sırasıyla Mersin, Konya ve } \\
\text { Bilecik olduğu tespit edilmiştir. }\end{array}$ \\
\hline $\begin{array}{l}\text { Yıldırım ve Önder } \\
\text { (2014) }\end{array}$ & $\begin{array}{l}\text { Evaluating potential freight villages in } \\
\text { İstanbul using multi criteria decision } \\
\text { making techniques }\end{array}$ & 7 & - & $\begin{array}{l}\text { Kriter } \\
\text { ağırlıklandırmada } \\
\text { AHP, çözüm için } \\
\text { PROMETHEE }\end{array}$ & $\begin{array}{l}\text { İstanbul (Silivri, Hadimkoy, Halkalı, } \\
\text { Pendik, Gebze, Tuzla) }\end{array}$ & $\begin{array}{l}\text { Lojistik köy için en uygun } 3 \text { bölgenin sırasıyla Silivri, Hadımköy } \\
\text { ve Halkalı olduğu tespit edilmiştir. }\end{array}$ \\
\hline Atalay vd. (2017) & $\begin{array}{l}\text { Türkiye'de lojistik merkezi yeri } \\
\text { seçiminde kriterlerin ahp ile } \\
\text { ağırlıklandırılması: Kars ili üzerine bir } \\
\text { analiz }\end{array}$ & 3 & 16 & $\begin{array}{l}\text { Kriter } \\
\text { ağırlıklandırmada } \\
\text { AHP, çözüm yok }\end{array}$ & Kars & $\begin{array}{l}\text { Lojistik köy yeri seçiminde ekonomik kriterlerin sosyal ve çevresel } \\
\text { kriterlere göre daha önemli olduğu tespit edilmiş ve Kars ili her bir } \\
\text { alt kriter açısından değerlendirilmiştir. }\end{array}$ \\
\hline $\begin{array}{l}\text { Demiroğlu ve Elener } \\
\text { (2014) }\end{array}$ & $\begin{array}{l}\text { Küresel lojistik köyleri ve Türkiye'de } \\
\text { kurulması planlanan lojistik köy } \\
\text { bölgelerinin ÇKKV yöntemleriyle } \\
\text { belirlenmesi }\end{array}$ & 5 & 19 & $\begin{array}{l}\text { Kriter } \\
\text { ağırlıklanndırmada } \\
\text { AHP, çözüm için } \\
\text { PROMETHEE }\end{array}$ & $\begin{array}{l}\text { Bandırma, H.Paşa, İskenderun, İzmir, İzmit, } \\
\text { Mersin ve Samsun'daki limanlar }\end{array}$ & $\begin{array}{l}\text { Lojistik köy yer seçiminde "Limandaki gemi kabul kapasitesi" en } \\
\text { yüksek ağırlık ile en önemli kriter olduğu tespit edilmiştir ve } \\
\text { sırasıyla lojistik köy potansiyeli açısından en uygun } 3 \text { limanın } \\
\text { Mersin, İzmir ve Haydarpaşa liman bölgesi olduğu tespit edilmiştir. }\end{array}$ \\
\hline Hamzaçebi vd. (2016) & $\begin{array}{l}\text { Selection of logistics center location } \\
\text { with MOORA method for black sea } \\
\text { region of Turkey. }\end{array}$ & 10 & - & MOORA & $\begin{array}{l}\text { Karadeniz Bölgesi (Amasya, Artvin, Bartın, } \\
\text { Bayburt, Bolu, Çorum, Düzce, Giresun, } \\
\text { Gümüşhane, Karabük, Kastamonu, Ordu, } \\
\text { Rize, Samsun, Sinop, Tokat, Trabzon, } \\
\text { Zonguldak) }\end{array}$ & $\begin{array}{l}\text { Lojistik köy için en uygun } 3 \text { bölgenin sırasıyla Samsun, Trabzon ve } \\
\text { Zonguldak olduğu tespit edilmiştir. }\end{array}$ \\
\hline $\begin{array}{l}\text { Onder ve Yildırım } \\
(2014)\end{array}$ & $\begin{array}{l}\text { Vikor method for ranking logistic } \\
\text { villages in Turkey }\end{array}$ & 8 & - & AHP ve VIIKOR & $\begin{array}{l}\text { Balıkesir (Gökköy), Denizli (Kaklık), } \\
\text { Erzurum (Palandöken), Eskişehir } \\
\text { (Hasanbey), İstanbul ( Halkalı), İzmit } \\
\text { (Köseköy), Kayseri (Boğazköprü), Konya } \\
\text { (Kayacık), Mersin (Yenice), Samsun } \\
\text { (Gelemen), Uşak (OSB) }\end{array}$ & $\begin{array}{l}\text { Lojistik köy için en uygun } 3 \text { bölgenin sırasıyla Samsun, Eskişehir, } \\
\text { İzmit olduğu tespit edilmiştir. }\end{array}$ \\
\hline
\end{tabular}


Demirkıran, Y., Öztürkoğlu, Ö. / Journal of Yasar University, 2020, 15/58, 347-367

Tablo 1. devam

\begin{tabular}{|c|c|c|c|c|c|c|}
\hline Önden vd. (2018) & $\begin{array}{l}\text { Evaluation of the logistics center } \\
\text { locations using a multi-criteria spatial } \\
\text { approach }\end{array}$ & 7 & - & $\begin{array}{l}\text { Kriter } \\
\text { ağırlıklanndırmada } \\
\text { Spatial analizi, } \\
\text { çözüm için F-AHP }\end{array}$ & TCDD'nin loj köy projesi olan 19 merkez & $\begin{array}{l}\text { Lojistik köy için en uygun yer seçiminde Yeşilbayır ve Halkalı } \\
\text { lojistik köyleri 1. sırada, İzmit ve Mersin 2. sırada, Kahramanmaraş } \\
\text { ve Kayseri lojistik köyleri ise } 3 \text {. sırada çımıştır. }\end{array}$ \\
\hline Uysal ve Yavuz (2014) & $\begin{array}{l}\text { Selection of logistics centre location } \\
\text { via ELEKTRE method: A case study in } \\
\text { Turkey }\end{array}$ & 11 & - & ELECTRE & $\begin{array}{l}\text { Zonguldak (Çaycuma, Merkez, Kozlu, } \\
\text { Kilimli, Alaplı, Devrek) }\end{array}$ & $\begin{array}{l}\text { Lojistik köy yeri seçiminde çevresel güvenlik en önemli kriter } \\
\text { olarak belirlenmiş ve alternatifler içinden Çaycuma'nın en iyi } \\
\text { potansiyel olduğu tespit edilmişţir. }\end{array}$ \\
\hline Özceylan vd. (2016) & $\begin{array}{l}\text { Evaluation of freight villages: A gis- } \\
\text { based multi-criteria decision analysis }\end{array}$ & 13 & - & $\begin{array}{l}\text { Kriter } \\
\text { ağırlıklanndırmada } \\
\text { ANP, çözüm için } \\
\text { TOPSíS }\end{array}$ & Ankara içinde 20 lokasyon & $\begin{array}{l}\text { A10, A14 ve A15 lokasyonları sırasıyla lojistik köy için en iyi } 3 \\
\text { lokasyon olarak saptanmıştır. }\end{array}$ \\
\hline Erkayman vd. (2011) & $\begin{array}{l}\text { A Fuzzy topsis approach for logistics } \\
\text { center }\end{array}$ & 4 & - & Fuzzy TOPSİS & Erzurum, Diyarbakır, Malatya & $\begin{array}{l}\text { Lojistik köy için en uygun } 3 \text { bölgenin sırasıyla Erzurum, Diyarbakı } \\
\text { ve Malatya olduğu tespit edilmiştir. }\end{array}$ \\
\hline Arıkan (2012) & Freight villages and an application & 7 & - & AHP & Bursa (Gemlik, Ovaakça, Badırga) & $\begin{array}{l}\text { Lojistik köy için en uygun } 3 \text { bölgenin sırasıyla Ovaakça, Badırga ve } \\
\text { Gemlik olduğu tespit edilmiştir. }\end{array}$ \\
\hline
\end{tabular}




\subsection{Türkiye’nin Düzey Bazlı Bölgeleri}

İstatistiki Bölge Birimleri Sınıflandırması (İBBS), Türkiye’nin AB üyelik sürecinde yerine getirmekle yükümlü olduğu kriterlerden biridir. Sınıflandırmanın amacı bölgesel tabanlı istatistikleri toplamak, sosyo-ekonomik analizler yapmak ve topluma yönelik bölgesel politikaların çerçevesini oluşturmak ve Avrupa düzeyinde karşılaştırılabilir verilerin üretilmesi olarak tanımlanmıştır. 2001'de Türkiye İstatistik Kurumu (TÜİK) ve Devlet Planlama Teşkilatı (DPT) tarafından hazırlanan İBBS raporu Türkiye Cumhuriyeti Bakanlar Kurulu'nun 2002/4720 sayılı Kararı ile 22 Eylül 2002 tarihli Resmi Gazetede yayımlanmıştır. Bu rapora göre, Türkiye'de üç kademeli bölge sistemi oluşturulurken, 81 ilin her biri "Düzey 3" olarak tanımlanmıştır. Ekonomik, sosyal ve coğrafi yönden benzerlik gösteren komşu iller ise bölgesel kalkınma planları ve nüfus büyüklükleri de dikkate alınarak "Düzey 2 (26 adet)" ve "Düzey 1 (12 adet)" bölgeleri olarak belirlenmiştir. Düzeyler bazında belirlenen bölgeler Tablo 2'de gösterildiği gibidir (Resmi gazete, 2002). Lojistik köylerin sadece bir şehre değil belli bir bölgeye hizmet etme amacının olmasıdan ve komşu iller arasında hem ticari hem de sosyal ilişkilerin olmasından dolayı, bu çalışmada İBBS'nin tanımladığı Düzey 2 bölgeleri analize konu edilmiştir.

Tablo 2. İstatistiki Bölge Birimleri Sınıflaması

\begin{tabular}{|c|c|c|c|c|c|}
\hline \multicolumn{2}{|c|}{$D \ddot{U Z E Y} 1$ (12 bölge) } & \multicolumn{3}{|c|}{$D \ddot{U Z Z E Y} 2$ (26 alt bölge) } & \multirow{2}{*}{$\begin{array}{l}\text { DÜZEY } 3 \text { (81 il) } \\
\text { Iller }\end{array}$} \\
\hline Düzey & Bölge & Düzey & Düzey kodu & Bölge & \\
\hline TR1 & İ́stanbul & 1 & TR10 & İstanbul alt bölgesi & İ̀̇stanbul \\
\hline \multirow{3}{*}{ TR2 } & \multirow{2}{*}{ Batı Marmara } & 2 & TR21 & Tekirdağ alt bölgesi & Tekirdağ, Edirne, Kırklareli \\
\hline & & 3 & TR22 & Balıkesir alt bölgesi & Balıkesir, Çanakkale \\
\hline & & 4 & TR31 & İzmir alt bölgesi & İzmir \\
\hline \multirow[t]{2}{*}{ TR3 } & \multirow[t]{2}{*}{ Ege } & 5 & TR32 & Aydın alt bölgesi & Aydın, Denizli, Muğla \\
\hline & & 6 & TR33 & Manisa alt bölgesi & Manisa, Afyonkarahisar, Kütahya, Uşak \\
\hline \multirow{2}{*}{ TR4 } & \multirow{2}{*}{ Doğu Marmara } & 7 & TR41 & Bursa alt bölgesi & Bursa, Eskişehir, Bilecik \\
\hline & & 8 & TR42 & Kocaeli alt bölgesi & Kocaeli (İzmit), Sakarya, Düzce, Bolu, Yalova \\
\hline \multirow{3}{*}{ TR5 } & \multirow{3}{*}{ Batı Anadolu } & 9 & TR51 & Ankara alt bölgesi & Ankara \\
\hline & & 10 & TR52 & Konya alt bölgesi & Konya, Karaman \\
\hline & & 11 & TR61 & Antalya alt bölgesi & Antalya, Isparta, Burdur \\
\hline \multirow[t]{2}{*}{ TR6 } & \multirow[t]{2}{*}{ Akdeniz } & 12 & TR62 & Adana alt bölgesi & Adana, Mersin \\
\hline & & 13 & TR63 & Hatay alt bölgesi & Hatay, Kahramanmaraş, Osmaniye \\
\hline \multirow{3}{*}{ TR7 } & \multirow{3}{*}{ Orta Anadolu } & 14 & TR71 & Kırıkkale alt bölgesi & Kırıkkale, Aksaray, Niğde, Nevşehir, Kırşehir \\
\hline & & 15 & TR72 & Kayseri alt bölgesi & Kayseri, Sivas, Yozgat \\
\hline & & 16 & TR81 & Zonguldak alt bölgesi & Zonguldak, Karabük, Bartın \\
\hline \multirow[t]{2}{*}{ TR8 } & \multirow[t]{2}{*}{ Batı Karadeniz } & 17 & TR82 & Kastamonu alt bölgesi & Kastamonu, Çankırı, Sinop \\
\hline & & 18 & TR83 & Samsun alt bölgesi & Samsun, Tokat, Çorum, Amasya \\
\hline TR9 & Doğu Karadeniz & 19 & TR90 & Trabzon alt bölgesi & Trabzon, Ordu, Giresun, Rize, Artvin, Gümüşhane \\
\hline \multirow{2}{*}{ TRA } & \multirow{2}{*}{ Kuzeydoğu Anadolu } & 20 & TRA1 & Erzurum alt bölgesi & Erzurum, Erzincan, Bayburt \\
\hline & & 21 & TRA2 & Ağrı alt bölgesi & Ağrı, Kars, Iğdır, Ardahan \\
\hline \multirow{3}{*}{ TRB } & \multirow{3}{*}{ Ortadoğu Anadolu } & 22 & TRB1 & Malatya alt bölgesi & Malatya, Elazı̆̆g, Bingöl, Tunceli \\
\hline & & 23 & TRB2 & Van alt bölgesi & Van, Muş, Bitlis, Hakkâri \\
\hline & & 24 & TRC1 & Gaziantep alt bölgesi & Gaziantep, Adıyaman, Kilis \\
\hline \multirow[t]{2}{*}{ TRC } & \multirow[t]{2}{*}{ Güneydoğu Anadolu } & 25 & TRC2 & Şanlıurfa alt bölgesi & Şanlıurfa, Diyarbakır \\
\hline & & 26 & TRC3 & Mardin alt bölgesi & Mardin, Batman, Şırnak, Siirt \\
\hline
\end{tabular}

\subsection{Kriterler}

Bölüm 1'de tartışıldığı üzere yapılan çalışmaların pek çoğunda lojistik köy yer seçimi kararında alternatiflerin değerlendirilmesinde nitel kriterler dikkate alınmıştır. Nitel kriterlerin değerlendirilmesi karar vericilerin konu ve bölge ile ilgili bilgi, tecrübe ve öngörüsüne bağlı olması karar sürecine öznellik katmaktadır. Ne kadar karar vericilerin nihai karar verme aşamasında sahip oldukları bilgi ve tecrübeler çok önemli olsa da onların doğru karar vermesini etkileyecek ön araştırmaların nesnel değerlendirilmelerden gelmesi özellikle stratejik kararların sonucunda elde edilecek faydayı artırabilecek veya zararı azaltabilecektir. Bu çalışmanın öncelikli amaçlarından birisinin Türkiye'de bölgelerin lojistik köy açısından potansiyellerinin ortaya konulması ve böylece karar vericilere bir yol haritası sunulması amaçlandığı için, bu çalışmada literatürde sadece nicel kriterler kullanılmıştır. Kullanılan bu kriterler Tablo 3'te gösterildiği üzere daha önceki çalışmalardan esinlenilerek belirlenmiştir. Kriterler konularına göre 4 ana kriter altında toplanmış ve toplamda 16 alt kriter belirlenmiştir. 
Demirkıran, Y., Öztürkoğlu, Ö. / Journal of Yasar University, 2020, 15/58, 347-367

Tablo 3. Ana Kriterler ve Alt Kriterler

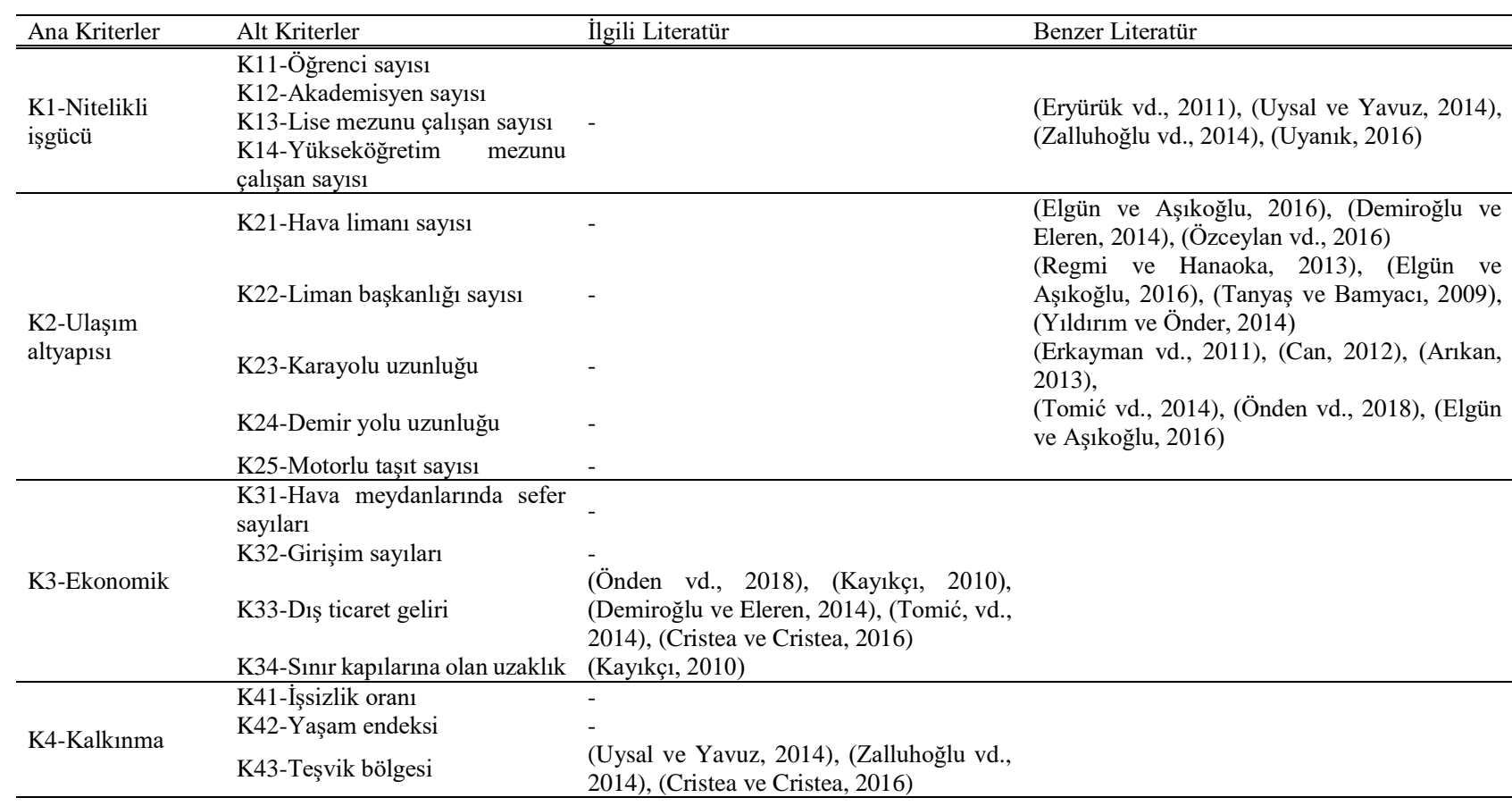

Çalışmamızın literatür kısmında bahsedildiği üzere Uyanık vd. (2018) lojistik köy yer seçim kararı ile ilgili literatürü incelemiş ve pek çok sayıda kriterin çeşitli çalışmalarda ele alındığını göstermiştir. Ancak, yaptığımız ön çalışma ve değerlendirmede bu kriterlerin bazılarının birbirini kapsadığı ve bazıları arasında da yüksek korelasyon çıktığı saptanmıştır. Bir sonraki paragrafta bu ön değerlendirme çalışması ve

Tablo 3’te belirlediğimiz kriterlerin açıklamaları detaylı bir şekilde tartışılmıştır.

Nitelikli iş gücü bulunabilirliği kriteri pek çok çalışmada dikkate alınan bir kriterdir (Uyanık vd., 2016; Uysal ve Yavuz, 2014; Eryürük vd., 2011). Lojistik köy veya üsler bir çok farklı ticaret ve lojistik ile ilgili hizmeti veren şirketleri kapsadığı için bunların yeri belirlenirken sektörün ihtiyaç duyduğu nitelikteki iş gücünün bulunabilirliği hayli önemlidir. Bu yüzden çalışmamızda bu kriter ana kriterlerden birisi olarak belirlenmiştir. $\mathrm{Bu}$ ana kriterin alt kırılımında bölgedeki öğrenci sayısı, akademisyen sayısı, lise mezunu çalışan sayısı ve yüksekokul mezunu çalışan sayısı alt kriterler olarak ele alınmıştır. Öğrenci sayısı ve çalışan sayıları lojistik köydeki firmalar için potansiyel iş gücü olarak görülmektedir. Ayrıca işgücü ana başlığı altında akademisyen sayısı kriterini ele alma sebebimiz, üniversitelerde çalışan akademisyenlerin lojistik köyün veya bir taşıma, depolama, aktarma sisteminin tasarlanması veya kurulması, lojistik köydeki firmaların teknik ve işletme bilgi birikimlerinin arttırılması ve muhtemel projelere destek olunması açısından önemli bir potansiyeli temsil etmektedir.

Bölgenin ulaşım altyapısının Tablo 3’te gösterildiği üzere literatürdeki pek çok çalışmada ele alınan ortak kriter olduğu gözlemlenmiş̧ir. Ancak ilgili literatürde ulaşım altyapısı konusunda genellikle havaalanına uzaklık, demiryoluna uzaklık, limana uzaklık, otoyollara olan uzaklık ya da altyapı olanakları gibi kriterlere yer verilmiştir. Çalışmamızın Türkiye'deki 81 ili kapsaması nedeniyle her şehrin demir yolu, karayolu, havaalanı ya da limana olan uzaklıkları bilgisi yerine her şehirde bulunan liman sayısı, havaalanı sayısı, karayolu uzunluğu ve demiryolu uzunluğu verileri ile çalışmanın daha uygun olduğu düşünülmüştür. Liman sayısı olarak da liman müdürlükleri sayıları hesaba katılmıştır. Motorlu taşıt sayısı her ildeki taşınan yük miktarının bir göstergesi olmasından dolayı bu kriter de ulaşım alt yapısı ana kriteri altında incelenmiştir. Toplam motorlu taşıt sayının belirlenmesinde ise o ildeki kamyon, kamyonet ve traktör sayıları toplamı ele alınmıștır.

Çalışmanın üçüncü ana kriteri ekonomik kriterdir. Bu ana kriter altında hava meydanlarındaki sefer sayıları, girişim sayıları, dış ticaret gelirleri, sınır kapılarına olan uzaklık alt kriterler olarak belirlenmiştir. Hava alanlarında yapılan havayolu yük taşımacılığı miktarı lojistik köy yeri seçiminde etkili olan kriterlerden biridir. İlgili kritere ait TÜiK'in web sitesinde hava meydanlarında iniş kalkış yapan toplam uçak sayısı (sefer sayısı) ve taşınan yük miktarı verilerine ulaşılmışıı ancak bu veriler arasında yüksek pozitif korelasyon (Korelasyon katsayısı: 0,986) çıkması sebebiyle kriter olarak sadece hava meydanlarındaki sefer sayıları ele alınmıştır. Hava meydanlarındaki sefer sayıları iç hat ve dış hat olarak gelen ve giden toplam uçak sayısını ifade etmektedir. Girişim sayıları her ildeki tarım, ormancılık, balıkçılık, madencilik, taş ocakçılı̆̆ 1 , imalat, inşaat, toptan ve perakende ticaret, ulaştırma ve depolama sektöründe faaliyet gösteren toplam girişim sayılarını ifade etmektedir. Verilerde depo sayıları da dahil olması sebebiyle depo sayısı şeklinde ayrıca bir kriter kullanılmamıştır. Dış ticaret gelirleri ithalat ve ihracat gelirlerinin toplamını ifade etmektedir. Sınır kapılarına olan uzaklık kriteri, Düzey 2 bölgelerinin Türkiye'de aktif olarak faaliyet gösteren tüm sinır kapılarına olan ortalama uzaklığını ifade etmektedir. Ticaret ana kriteri altında yapılan çalışmalarda genellikle organize sanayi bölgesi (OSB) ya 
da serbest bölge sayıları da dikkate alınmıştır. Ancak çalışmamızda girişim sayıları kullanılmıştır. Bu girişim sayılarının bir kısmı OSB ler içinde bir kısmı ise dışında yer almaktadır. Dolayısı ile hem OSB yi hem girişim sayılarını kriter olarak ele aldığımız takdirde verilerin bir kısmı iki kez değerlendirilmiş olacaktır. Bu nedenle bu çalışmada sadece girişim sayıları kriter olarak kullanılmıştır. Serbest bölgelerin dış ticaret hacminin bir göstergesi olduğundan dış ticaret gelirleri kriteri tekrar etmiş olacaktır. Bu nedenle serbest bölge sayısı da aynı şekilde tekrarı engellemek amacıyla çalışmaya dahil edilmemiştir.

Çalışmamızda literatürdeki diğer çalışmalardan farklı olarak kalkınma ile ilgili ana kriter ve ilgili alt kriterler ele alınmıştır. Çok az çalışmada (Cristea ve Cristea, 2016; Uysal ve Yavuz, 2014; Zalullah vd., 2014), devlet teşviği kriteri dikkate alınmıştır. Lojistik köyler genellikle devlet kontrolünde kurulan ve işletilen merkezlerdir ve bu çalışmanın temel amacı Türkiye'de yeni bir lojistik köy kurulması kararını veren yetkililere bir yol haritası sunmaktır. Bu yol haritasının belirlenmesinde ülkenin kalkınma konusunun da çalışmaya dahil edilmesi gerektiğini düşünmekteyiz. Bu nedenle kalkınma ana kriteri altında işsizlik oranı, yaşam endeksi ve teşvik bölgesi alt kriterlerine yer verilmiştir. Yaşam endeksi, konut, çalışma hayatı, gelir ve servet, sağlık, eğitim, çevre, güvenlik, sivil katılım, altyapı hizmetlerine erişim, sosyal yaşam ve yaşam memnuniyeti olmak üzere, 11 boyutu kapsayan ve bu boyutları tek bir bileşik endeks yapısı içinde sunan bir kriterdir (TÜİK, 2015) . İllerin kalkınmışlık seviyesinin önemli bir göstergesidir. İllerdeki işsizlik oranı ve illerin teşvik bölgesi katsayısı da kalkınma ana kriteri altında ele alınmıştır.

Çalışmamızda pek çok çalışmanın ele aldığı arazi kriteri değerlendirmeye dahil edilmemiştir. Lojistik köylerin genellikle devlet kontrolünde kurulan merkezler olması sebebiyle Türkiye'nin herhangi bir şehrine lojistik köy kurulması durumunda arazi bulunabilirliği konusunda yeterli imkan olduğu düşünülmektedir. Daha önce yapılmış çalışmalarda (Ballis ve Mavrotas, 2007; Elgün ve Aşıkoğlu, 2016; Özceylan vd., 2016), genellikle bir şehir ya da bir bölge içinde, uygun konumun aranması sebebiyle arazi bulunabilirliği karar vermede önemli rol oynamakta idi ancak çalışmamızda her ilde mutlaka lojistik köy için uygun bir devlet arazisinin bulunabileceği varsayılmıştır ve bu nedenle arazi bulunabilirliği, genişleme olanağı ya da arazi maliyeti gibi kriterlere çalışmada yer verilmemiştir. Ayrıca elektrik, su, kanalizasyon gibi alt yapı olanaklarının lojistik köy kurulması halinde araziye getirilebileceği düşünülmektedir. Dolayısı ile yer seçiminde alt yapı olanaklarının da çok önemli olmadığı düşünülmekte ve kriter olarak kullanılmamaktadır.

Literatürde yapılan bazı çalışmalarda iç su yollarına yakınlık (Özceylan vd., 2016), liman derinliği (Demiroğlu ve Eleren, 2014), hinterland genişliği (Küçük vd., 2017), elleçleme maliyeti, elleçleme kapasitesi (Hamzaçebi vd., 2016), depo sayısı (Ballis ve Mavrotas, 2007) gibi kriterler de dikkate alınmıştır ancak çok az çalışmada bu kriterler ile karşılaşılmıştır. Çalışmamızda iç su yollarına yakınlığın 81 il düzeyinde etkileyici bir kriter olmadığı düşünülmüştür. Liman derinliği ya da liman ardı bölge genişliği, elleçleme kapasitesi ya da maliyeti gibi kriterler de dikkate alınmamıştır çünkü liman kapasitesi ihtiyaç duyulduğu taktirde ek inşalar ya da ek ekipman ile artırılabilir ancak sıfırdan bir liman inşa etmek hem maliyet hem de zaman açısından çok daha zordur. Dolayısı ile bizim için önemli olan bölgelerde liman olup olmamasıdır. Bu nedenle sadece liman sayısını kriter olarak kullandık.

\subsection{Yöntem}

Çalışmamızda çözüm yöntemi olarak karar vericinin kararını etkileyen pek çok kriterin varlığı durumunda çeşitli alternatifler arasından bir seçim yapması gerektiğinde kullanılan çok kriterli karar verme (ÇKKV) yöntemlerinden biri olan PROMETHEE (Preference Ranking Organization Method for Enrichment Evaluations) kullanılmıştır. Yöntem diğer ÇKKV yöntemlerinden farklı olarak karar vericiye alternatifleri karşılaştırırken tek bir tercih fonksiyonu yerine her bir kriter için farklı tercih fonksiyonu kullanabilme olanağı tanımaktadır. Bu şekilde karar verici gerçek yaşam problemlerinde olduğu gibi kriter yapıları birbirinden farklı olması durumunda her bir kriter altında alternatifleri değerlendiriken farklı bir yol izleyebilmektedir. Bu nedenle bu çalışmada PROMETHEE yöntemi tercih edilmiştir. Yöntem 1982 yılında Brans tarafından geliştirilmiştir (Brans, 1982) ve 1985 yılında genişletilmiştir (Brans ve Vincke, 1985). Yöntem üstünlüğe dayalı sıralama yaparak karar vericiye yön göstermektedir. Promethee yönteminin uygulanabilmesi için kriter ağırlıkları ve her bir alternatifin kriterlere ilişkin değerleri bilgisine ihtiyaç vardır. Diğer ÇKKV yöntemlerinden farkı alternatiflerin değerlendirilmesinde tercih fonksiyonlarının kullanılmasıdır. Promethee yöntemi karar vericilere alternatiflerin hem kısmi (PROMETHEE I) hem de tam sıralamasını (PROMETHEE II) yaparken problemin geometrik temsilini iki boyutlu düzlemde sonuçlarıyla birlikte verebilmektedir. Çalışmamızda sadece PROMETHEE II ile tam siralama yapılmaktadır.

Yöntemin uygulama adımları şu şekildedir:

Adım1: Kriterler, ağırlıkları $\left(w_{1}, w_{2}, w_{3}, \ldots, w_{k}\right)$ ve her bir alternatifin $(a, b, c)$ kriterlere göre değerleri belirlenir.

Adım2: Kriterler için kullanılacak tercih fonksiyonları ve eşik değerleri tanımlanır. Bir alternatifin diğerine göre üstünlüğüne nasıl karar vereceğini belirlemede tercih fonksiyonları (bkz. Tablo 4) kullanılır. Bu fonksiyonlar belirlendikten sonra her fonksiyon tipi için eşik değerlerin belirlenmesi gerekmektedir. Bir alternatifin diğerine göre üstünlük sağladığı nokta eşik değer olarak adlandırılmaktadır. Promethee II yönteminde kullanılan tercih fonksiyonları ve alternatiflerin üstünlüklerinin tespit edilmesinde dikkate alınan eşik değerler Tablo5'te gösterilmiştir. 
Tablo 4.Tercih Fonksiyonları

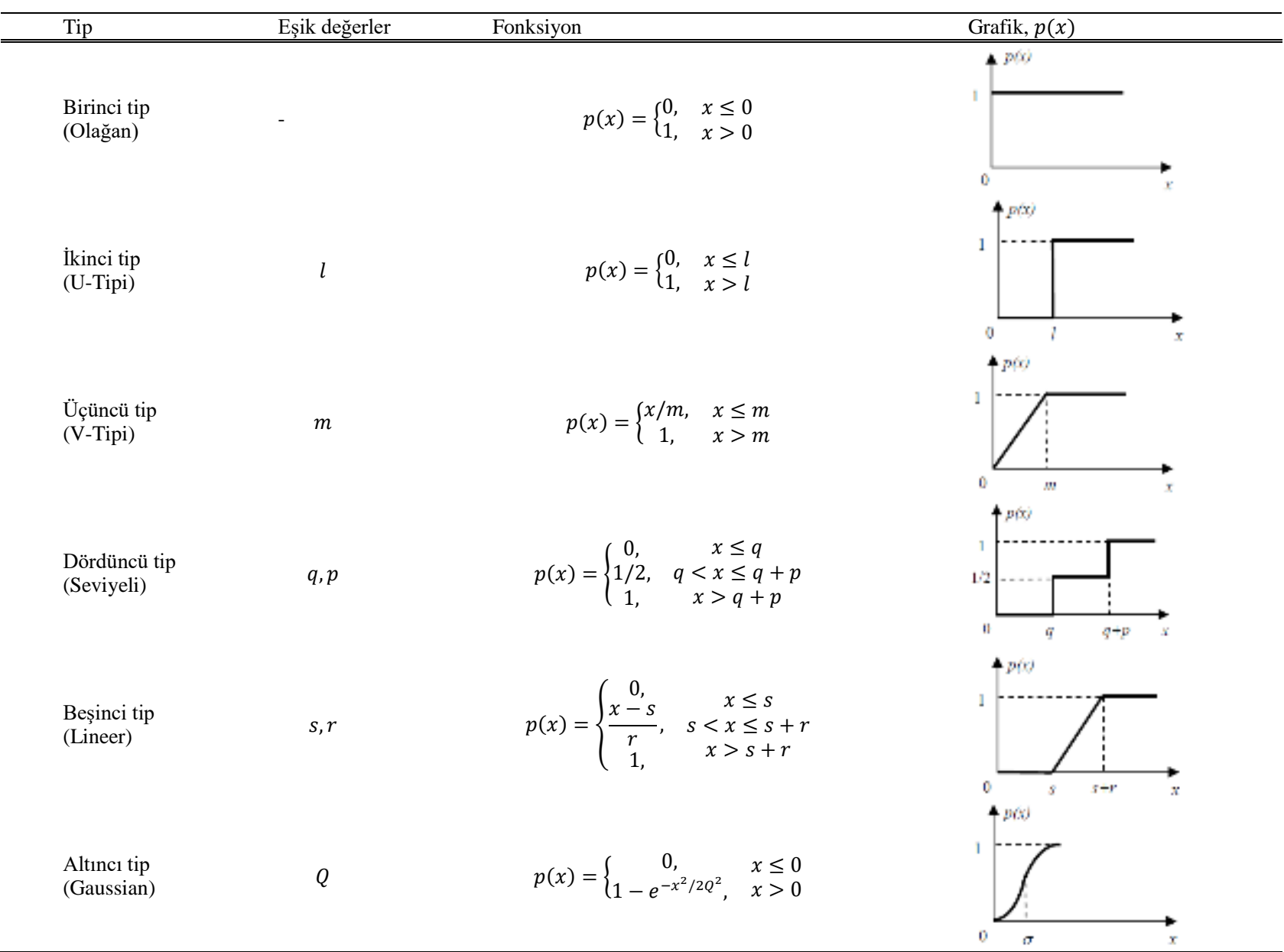

Kaynak: Brans ve Vincke, Preference ranking organisation method, 1985.

Adım3: Tercih fonksiyonları baz alınarak alternatif çiftleri için Eş.1 kullanılarak "ortak tercih fonksiyonları" belirlenir. Karar verici alternatifler arasında kıyaslama yaparak her alternatif çiftinin arasındaki farkları değerlendirir.

$$
P(a, b)=\left\{\begin{array}{c}
0 \quad, f(a) \leq f(b) \\
p[f(a)-f(b)], f(a)>f(b)
\end{array}\right.
$$

Adım4: Alternatif çiftleri için “tercih indeksleri”nin hesaplanması. $w_{i}$ ağırlı̆̆ına sahip olan $k$ kriter açısından değerlendirilen $a$ ve $b$ alternatiflerinin tercih indeksleri Eş. 2 kullanılarak hesaplanır.

$$
\pi(a, b)=\sum_{i=1}^{k} w_{i} \cdot P_{i}(a, b)
$$

Adım5: Alternatifler için pozitif $\left(\Phi^{+}\right)$ve negatif $\left(\Phi^{-}\right)$üstünlükler belirlenir. Pozitif üstünlükler Eş.3 negatif üstünlükler ise Eş.4 ile hesaplanır.

$$
\begin{aligned}
& \Phi^{+}=\sum_{i}^{k} \pi(a, x) \\
& \Phi^{-}=\sum_{i}^{k} \pi(x, a)
\end{aligned}
$$

Adım 6: Alternatifler için tam öncelikler Eş.5 ile hesaplanır.

$$
\Phi(a)=\Phi^{+}(a)-\Phi^{-}(b)
$$

$a$ ve $b$ gibi iki alternatif için hesaplanan tam öncelik değerlerine bakılarak aşağıdaki iki karar alınabilir.

$\Phi(a)>\Phi(b)$ ise a alternatifi b ye tercih edilir.

$\Phi(a)=\Phi(b)$ ise a ve b alternatifi farksızdır. 


\section{Uygulama}

Uygulama çalışması üç aşamadan oluşmaktadır. Birinci aşama belirlenen kriterlerin karar vericilerin önemlerini gösterecek şekilde ağırıklandırılmasıdır. İkinci aşama ise her bir kriter ve alternatif için gerekli verilerin toplanmasıdır. Son aşamada ise alternatifler Promethee yöntemi ile sıralanmıştır.

\subsection{Kriter Ăğıllkları}

Çalışmamızda lojistik köy kuruluş yeri seçiminde dikkate alınacak ana kriter ve bunların altında yer alan alt kriterler daha önce Tablo 3'te açıklanmıştır. Bu kriterlerin ağırlıkları karar verme aşamasında hem uzmandan uzmana hem de zaman içerisinde değişebilmektedir. Bu nedenle çalışmada herbir kriterin ağırlıklarının farklı senaryolar altında incelenmesine karar verilmiştir. Senaryolara bağlı kriter ağıllıkları sektörel tecrübesi olan 5 akademisyen görüşü ile delphi tekniği kullanılarak oluşturulmuştur. Senaryolar, kriterler arasındaki ağırlık farkları ile oluşturulacağı için aralarında anlamlı bir fark olması gerektiği konsensusu ile ağırlıklar belirlenmiştir. Delphi tekniği turları sonucunda ana kriter ağırlıkları, toplamları \%100 olacak şekilde sırasıyla \%10, 20, 30 ve 40 olarak belirlenmiştir. Bu şekilde kriterlerin önem seviyeleri sırasıyla çok az önemli, biraz önemli, önemli ve çok önemli’yi ifade etmektedir. Dört ana kriter ve dört seviye ile toplamda 4 ! yani 24 farklı ağırlık kümesi elde edilmiştir (bakınız Tablo 6). Her bir ana kriterin altında yer alan alt kriterlerin birbirine karşı önem açısından üstün olmadıkları varsayılmıştır. Böylece alt kriterlerin ağırlıkları kendi aralarında eşit olacak şekilde dağıtılmıştır. Örneğin iş gücü ana kriteri altında 4 alt kriter bulunmaktadır. Bu nedenle her bir alt kriterin ağırlığı $\% 25$ 'dir. Sonuç olarak her bir senaryo için alt kriter ağırlıkları kendilerinin ana kriter ağırlıkları ile çarpılmasıyla yeniden elde edilmiştir. Tüm senaryolarda çalışılan kriter ağırlıkları Tablo 6'da gösterilmiştir.

\subsection{Veriler}

Alternatif bölgelerin kriterlere göre aldığı değerler Tablo 7'de gösterilmiştir. Veriler çözümde kullanılan Visual Promethee adlı programa girilirken kriterin özelliğine göre amaç fonksiyonlarının maksimizasyon ya da minimizasyon olduğuna karar verilmiştir. Çalışmamızda öğrenci sayısı, akademisyen sayısı, lise mezunu çalışan sayısı, yükseköğretim mezunu çalışan sayısı, havalimanı sayısı, liman sayısı, karayolu uzunluğu, demiryolu uzunluğu, motorlu taşıt sayısı, dış ticaret gelirleri, girişim sayısı, uçuş sefer sayıları, işsizlik oranı, teşvik bölgesi kriterleri için amaç maksimizasyon olarak belirlenmiştir. Bu kriterler için alternatiflerin aldığı değerlerin yüksek olması ilgili alternatifin lojistik köy yeri için iyi bir potansiyel olduğunu göstermektedir. İşsizlik oranı ve teşvik bölgesi kriterleri için alternatif bölgelerin değerlerinin yüksek olması olumlu bir gösterge değildir ancak lojistik köy kurulacak yerin bu iki kriter açısından zayıf olan bölgelerde olması halinde ülkenin kalkınma dağılımına olumlu bir katkı sağlanacağı düşünülmektedir. Bu nedenle işsizlik oranının yüksek olduğu bölgelerin lojistik köy yeri seçiminde öncelikli olması beklenmektedir. Teşvik bölgesi kriterinde bölgeler devlet tarafından desteklenme ihtiyacı açısından değerlendirilmiş ve ihtiyaç derecesine göre 1-6 arasında puanlar almışlardır. Devlet teşviğinden en çok yararlanacak bölgeler 6, en az yararlanacak bölgeler 1 puan almaktadır (Invest in Turkey, 2018). Bu nedenle çalışmada teşvik puanı yüksek olan bölgelerin lojistik köy yeri seçiminde öncelikli olması beklenmektedir.

Sınır kapısı mesafesi ve yaşam endeksi kriterlerinde amaç olarak minimizasyon belirlenmiştir. Her bir alternatif bölge için sınır kapısı mesafesi o bölge içinde yer alan şehirlerin Türkiye'de aktif olarak faaliyette bulunan sınır kapılarına (Akçakale, Aktaş (Çıldır), Aziziye (Dereköy), Cilvegözü, Çobanbey, Dilucu, Esendere, Gürbulak, Habur, Hamzabeyli, İpsala, Kapıköy, Kapıkule, Karaağaç (Pazarkule), Karkamış, Öncüpınar, Posof (Türkgözü), Sarp, Yayladağı, Nusaybin, Üzümlü) olan uzaklıklarının ortalaması alınarak belirlenmiştir. Bölgelerin sınır kapılarına yakın olması o bölgeyi lojistik köy kurulum yeri açısından avantajlı kılmaktadır. Bu nedenle sınır kapılarına daha yakın olan bölgelerin yani sınır kapılarına ortalama uzaklığı kısa olan bölgelerin lojistik köy yeri açısından öncelikli olması beklenmektedir. Yaşam endeksi kriteri açısından bölgeler değerlendirilirken endeksi küçük olan yani konut, çalışma hayatı, gelir ve servet, sağlık, eğitim, çevre, güvenlik, sivil katılım, altyapı hizmetlerine erişim, sosyal yaşam ve yaşam memnuniyeti açısından kalkınmaya daha çok ihtiyacı olan bölgelerin öncelikli olması beklenmektedir. Bu nedenle bahsedilen iki kriterde amaç minimizasyon olarak belirlenmiştir.

Alternatif bölgelerin öğrenci sayısı kriterine ilişkin değerleri belirlenirken her bölgedeki öğrenim gören öğrenci sayılarından ilgili bölgelerde açık ya da uzaktan eğitim alan öğrenci sayıları çıkartılmıştır (YÖK, 2018). Çünkü açık ya da uzaktan eğitim alan öğrencilerin üniversitenin bulunduğu bölgeden farklı bir bölgede olabilecekleri için bir bölgedeki işgücü potansiyelini ifade etmediği düşünülmektedir. Kara yolu uzunluğu bilgisi için köy yolu, il yolu ve otoyol uzunluklarının toplamları alınmıştır ancak illerin yüz ölçümlerinin farklılık göstermesi sebebiyle yüz ölçümü küçük olan illerde haliyle karayolu ya da demiryolu uzunlukları kısa olmaktadır. Yüz ölçümü açısından küçük olan illerdeki bu dezavantajı ortadan kaldırmak amacıyla daha adil bir karşılaştırma yapabilmek için her ilin demiryolu ve karayolu uzunlukları yerine her ilin yüz ölçümüne düşen karayolu uzunluğu (karayolu yoğunluğu) ve yüz ölçümüne düşen demiryolu uzunluğu (demiryolu yoğunluğu) kullanılmıştır ve Düzey 2 bazında toplamları alınmıştır. Motorlu taşıt sayısının belirlenmesinde ise bölgelerdeki kamyon, kamyonet ve traktör sayıları toplamını ele alınmıştır. 
Demirkıran, Y., Öztürkoğlu, Ö. / Journal of Yasar University, 2020, 15/58, 347-367

Alternatif bölgelerin değerlerinin Visual Promethee programına girilmesinden sonra her kriter için tercih fonksiyonları ve tercih fonksiyonlarında kullanılacak eşik değerlerler belirlenmiştir (bakınız Tablo 5Tablo 5).

Tablo 5. Kriterlere Göre Belirlenmiş Tercih Fonksiyonları ve Eşik Değerleri

\begin{tabular}{|c|c|c|}
\hline Alt Kriterler & Tercih Fonksiyonu & Eşik Değerler \\
\hline K11-Öğrenci sayısı & 5. tip (Lineer) & $\begin{array}{c}\mathrm{s}=10.000 \\
\mathrm{~s}+\mathrm{r}=100.000\end{array}$ \\
\hline K12-Akademisyen sayısı & 5. tip (Lineer) & $\begin{array}{c}s=1.000 \\
s+r=10.000\end{array}$ \\
\hline K13-Lise mezunu çalışan sayısı & 5. tip (Lineer) & $\begin{array}{c}s=10.000 \\
s+r=500.000\end{array}$ \\
\hline K14-Yükseköğretim mezunu çalışan sayısı & 5. tip (Lineer) & $\begin{array}{c}s=10.000 \\
s+r=500.000\end{array}$ \\
\hline K21-Hava limanı sayısı & 3. tip (V-tipi) & $\mathrm{m}=2$ \\
\hline K22-Liman başkanlığı sayısı & 1. tip (Olağan) & - \\
\hline K23-Karayolu uzunluğu & 3. tip (V-tipi) & $\mathrm{m}=0,27$ \\
\hline K24-Demir yolu uzunluğu & 3. tip (V-tipi) & $\mathrm{m}=0,01$ \\
\hline K25-Motorlu taşıt sayısı & 3. tip (V-tipi) & $\mathrm{m}=156.150$ \\
\hline K31-Hava meydanlarında iniş kalkış yapan uçak sayısı & 6. tip (Gaussian) & - \\
\hline K32-Girişim sayıları & 5. tip (Lineer) & $\begin{array}{c}s=10.000 \\
s+r=100.000\end{array}$ \\
\hline K33-Diş ticaret geliri & 5. tip (Lineer) & $\begin{array}{c}s=10.000 .000 \\
s+r=50.000 .000\end{array}$ \\
\hline K34-Sınır kapılarına olan uzaklık & 6. tip (Gaussian) & - \\
\hline K41-İşsizlik oranı & 6. tip (Gaussian) & - \\
\hline K42-Yaşam endeksi & 3. tip (V-tipi) & $\mathrm{m}=0,187$ \\
\hline K43-Teşvik bölgesi & 2. tip (U-tipi) & $1=0,9$ \\
\hline
\end{tabular}

\subsection{Bulgular}

Türkiye'de lojistik köy yer seçimi konulu çalışmamızda istatistiki bölge sınıflamasına göre Düzey 2 'de yer alan 26 bölgenin belirlediğimiz seçim kriterleri açısından potansiyelleri incelenmiştir. Seçim kriterlerinin belirlenmesinden sonra hangi kriterin ne kadar önemli olduğu kararı verilmeye çalışılmıştır ancak bu kararın kişiden kişiye değişebilmesi nedeniyle çalışmamızda her ana kriter 4 farklı önem düzeyinde ele alınmış toplamda 24 senaryo altında alternatif bölgelerin değerlendirilmesi yapılmıştır. Her bir senaryo için elde edilen sonuçlar Tablo 8'de gösterilmiştir. Tablo 8' de görüldüğü üzere TR10 bölgesi (İstanbul) bütün senaryolarda yani ağırlık setleri ne olursa olsun lojistik köy potansiyeli açısından 1. sırada çıkmıştır. TR10 bölgesinde hâlihazırda TCDD ve Altyapı Yatırımları Genel Müdürlüğünün (AYGM) bağlı olduğu Ulaştırma, Denizcilik ve Haberleşme Bakanlığı'nın faaliyete geçirdiği Halkalı lojistik köyü bulunmaktadır ayrıca Yeşilbayır lojistik köyü de proje aşamasındadır. Bölgede şu anda 2 adet lojistik köy projesi olması çalışmanın sonucunu doğrular niteliktedir. İstanbul'un pek çok kriter açısından en iyi düzeyde olması sebebiyle sıralama içinde kısmi olarak sapmalara neden olabileceğinden çalışma bir de İstanbul elimine edilerek değerlendirilmiştir. Elde edilen yeni sonuçlar Tablo 9'da gösterilmiştir. Bu yeni değerlendirmede sıralamalar tabloda görüldüğü üzere kısmen değişmiştir. Bu yeni değerlendirmede elde edilen sonuçlar karar vericilere ışı tutması açısından aşağıda bahsedilen yaklaşım ile özetlenmiştir.

Ana kriterlerin ağırlıkları 4 farklı önem düzeyinde ele alınmıştı. Özet sonuçlar için her bir ana kriterin "çok önemli” olduğu ağırlık senaryolarında çıkan sıralamalardaki ilk 5'te yer alan bölgeler ve bunların kaçıncı sırada yer aldıkları dikkate alınmıştır. Buna göre, ana kriterlerin çok önemli olduğu senaryolar şu şekildedir. Nitelikli iş gücü için senaryo 19, 20, 21, 22, 23 ve 24; ulaşım altyapısı için senaryo 5, 6, 11, 12, 17 ve 18; ekonomi için senaryo 2, 4, 8, 10, 14 ve 16; ve kalkınma için senaryo $1,3,7,9,13$ ve 15 .

Şekil 1 nitelikli işgücü kriterinin çok önemli olduğu diğer kriterlerin kıyasla daha az önemli olduğu 6 senaryoda ilk 5 sıralamada hangi bölgelerin hangi senaryoda kaçıncı sırada yer aldığını göstermektedir. Bölgelerin grafikte merkeze yakın olması nitelikli işgücü potansiyeli açısından sıralamada önde geldiğini göstermektedir. Bu durumda nitelikli işgücünün varlığına çok önem veren bir karar verici için lojistik köy kurulabilecek potansiyele sahip en önemli bölgeler sirasıyla TR51 (Ankara), TR 42 (İzmit, Sakarya, Düzce, Bolu, Yalova), TR31 (İzmir), TR41 ( Bursa, Eskişehir, Bilecik) ve TR90 (Trabzon, Ordu, Giresun, Rize, Artvin, Gümüşhane) bölgeleridir. 
Demirkıran, Y., Öztürkoğlu, Ö. / Journal of Yasar University, 2020, 15/58, 347-367

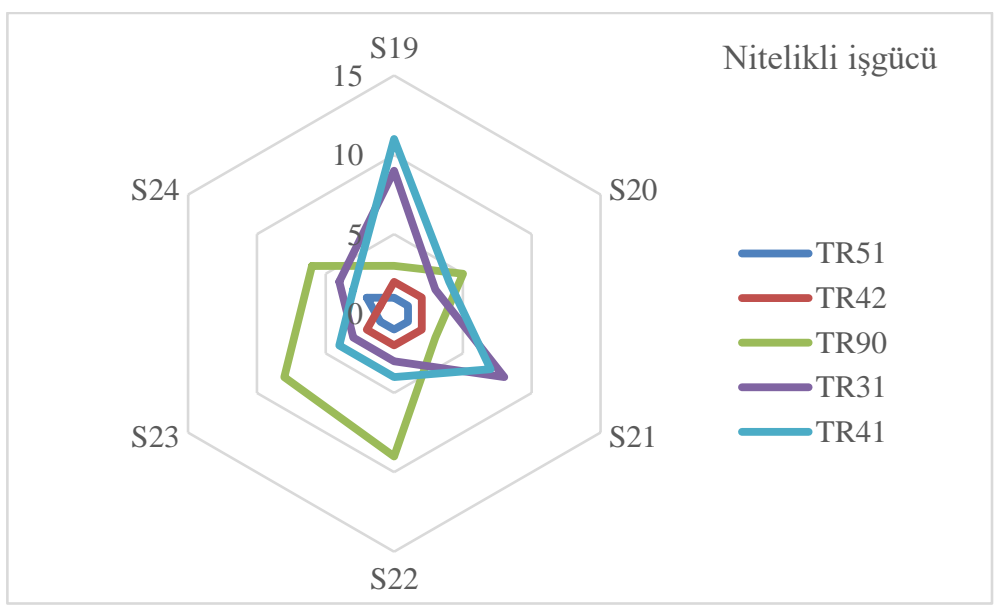

Şekil 1. Nitelikli İşgücü Kriterinin Önemli Olduğu Senaryolarda Sıralamada İlk 5 Bölge

Nitelikli işgücü açısından yapılan değerlendirmede elde edilen sonuçlarda ilk sırada yer alan beş bölge nüfus açısından en kalabalık olan bölgelerdir. Dolayısı ile öğrenci sayıları ve çalışan sayıları açısından bu bölgelerin ilk sıralarda yer alması kaçınılmazdır. Birinci sırada yer alan TR51 bölgesinde 45 uluslararası nakliye şirketi tarafından kurulmuş olan Ankara lojistik üssü bulunmaktadır. İkinci sırada yer alan TR42 bölgesindeki illerden İzmit'de TCDD'nin inşa ettiği Köseköy lojistik merkezi bulunmaktadır. Üçüncü sırada yer alan TR31 bölgesinde tamamlanmış bir lojistik köy bulunmamaktadır ancak Kemalpaşa ilçesinde inşası devam eden bir köy projesi bulunmaktadır. Dördüncü sırada yer alan bölge illerinden Eskişehir'de Hasanbey lojistik köyü tamamlanmış ve hizmete girmiştir, ayrıca Bilecik'de Bozüyük lojistik köyünün inşası devam etmektedir. Beşinci sırada yer alan TR90 bölgesinin hiç bir ilinde lojistik köy bulunmamaktadır. Nitelikli işgücü potansiyeli açısından bu bölge lojistik köy kurmaya elverişli bir bölgemizdir.

Şekil 2'de ulaşım altyapısı kriterinin çok önemli olduğu diğer kriterlerin kıyasla daha az önemli olduğu 6 senaryo için bölgelerin sıralaması gösterilmiştir. Ulaşım altyapı olanaklarının karar vericiler için en önemli kriter olması durumunda grafikte merkeze en yakın olan bölge yani sıralamada en önde bulunan bölge TR42 (İzmit, Sakarya, Düzce, Bolu, Yalova) bölgesidir. Sıralamayı sırasıyla TR41 (Bursa, Eskișehir, Bilecik), TR31 (İzmir), TR90 (Trabzon, Ordu, Giresun, Rize, Artvin, Gümüşhane) ve TR 32 (Aydın, Denizli, Muğla) bölgeleri takip etmektedir. İlk 3 sırada yer alan TR42, TR41, TR31 bölgelerinde mevcut olan lojistik köylerden bir önceki paragrafta bahsedilmiştir. TR90 bölgesinin hiç bir ilinde lojistik köy bulunmamaktadır. Beşinci sırada yer alan TR32 bölgesinin illerinden Denizli'de Kaklık lojistik köyü bulunmaktadır. Nitelikli işgücü ve ulaşım kriterleri açısından yapılan değerlendirme sonucunda elde dilen sıralamalar benzerlik göstermiştir.

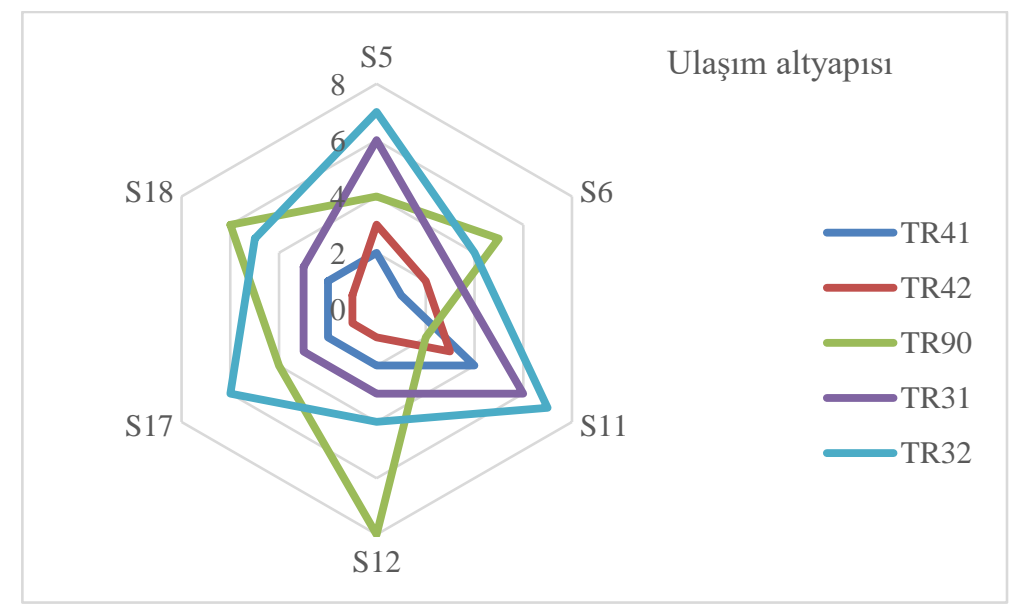

Şekil 2. Ulaşım Altyapısı Kriterinin Önemli Olduğu Senaryolarda Sıralamada İlk 5 Bölge

Şekil 3'te ekonomik kriterinin çok önemli olduğu diğer kriterlerin kıyasla daha az önemli olduğu 6 senaryo için bölgelerin sıralaması gösterilmiştir. Sıralamada en önde gelen bölge TR42 (İzmit, Sakarya, Düzce, Bolu, Yalova) bölgesidir. Sıralamayı sırasıyla şu bölgeler takip etmektedir: TR31 (İzmir), TR41 ( Bursa, Eskişehir, Bilecik), TR51 (Ankara), TR32 (Aydın, Denizli, Muğla). Ekonomik açıdan bölgelerin değerlendirilmesinde ilk sıralarda yer alan bölgeler nitelikli işgücü ve ulaşım altyapısının çok önemli olduğu durumlarda ilk sırada yer alan bölgeler ile büyük ölçüde benzerlik göstermektedir. İlgili bölgelerde hâlihazırda mevcut olan lojistik köylerden önceki paragraflarda bahsedilmiştir. 
Demirkıran, Y., Öztürkoğlu, Ö. / Journal of Yasar University, 2020, 15/58, 347-367

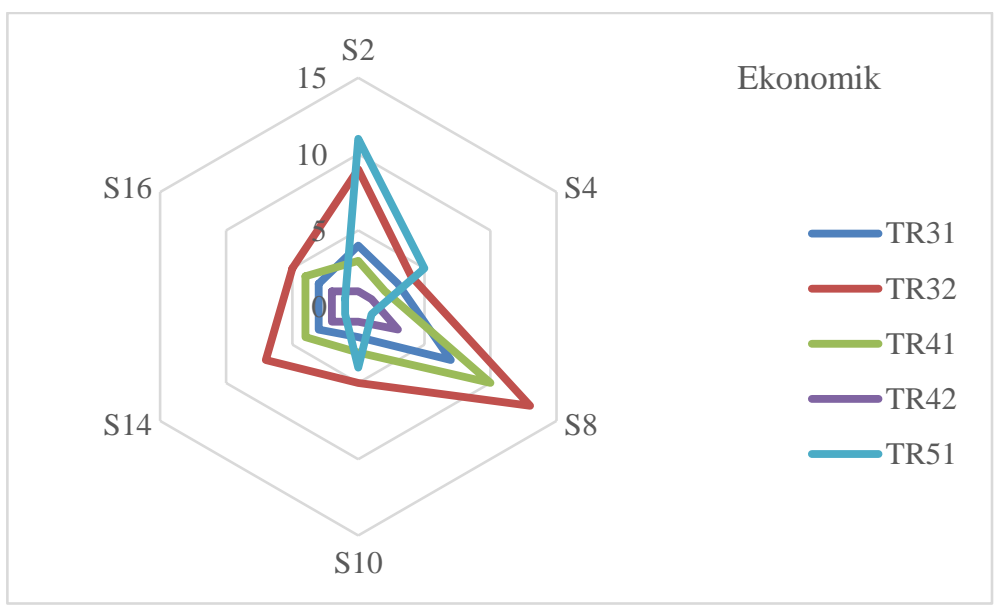

Şekil 3. Ekonomik Kriterlerin Önemli Olduğu Senaryolarda Sıralamada İlk 5 Bölge

Şekil 4'de kalkınma kriterinin en önemli olduğu diğer kriterlerin kısmen daha az önemli olduğu durumdaki 6 senaryonun yani 6 farklı kriter ağırlığı setinin sonuçları bulunmaktadır. Sıralamada en önde gelen bölge TRA2 (Ağrı, Kars, Iğdır, Ardahan) bölgesidir. Türkiye'nin doğusunda yer alan bölge diğer bölgelere kıyasla işgücü, ulaşım altyapısı, ekonomik değerlerin daha düşük olduğu bir bölgedir. Nitelikli işgücü, ulaşım altyapısı ve ekonomik açıdan diğer bölgelere kıyasla daha düşük değerlere sahip iken kalkınma kriteri ön plana çıktığında potansiyeli yüksek olduğu için sıralamada üst sırada çıkmıştır. Sonrasında sırasıyla TRB2 (Van, Muş, Bitlis, Hakkari), TRB1 (Malatya, Elazı̆g, Bingöl, Tunceli), TRC1 ( Gaziantep, Adıyaman, Kilis), TRC2 (Şanlıurfa, Diyarbakır) bölgeleri kalkınma açısından yüksek potansiyele sahip bölgelerdir. Birinci sırada yer alan TRA2 bölgesinde proje aşamasında Kars lojistik köyü ve ikinci sırada yer alan TRB2 bölgesi illerinden Bitlis’te proje aşamasında olan Tatvan lojistik köyü bulunmaktadır. Sıralamayı takip eden sonraki üç bölgede herhangi bir lojistik köy bulunmamaktadır.

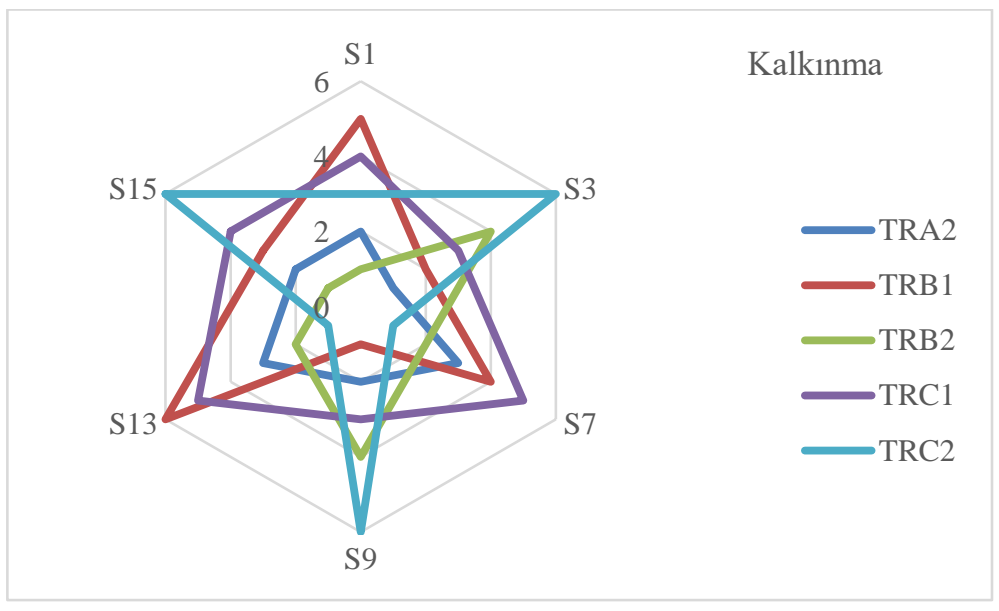

Şekil 4. Kalkınma Kriterinin Önemli Olduğu Senaryolarda Sıralamada İlk 5 Bölge

\section{Sonuç}

Bu çalışmada stratejik seviyede bir karar problemi olan lojistik köy veya üs yer seçimi problemi ele alınmıştır. Çalışmanın nihai amacı lojistik köy yer seçimi kararını etkileyen kriterleri farklı senaryolar altında değerlendirerek Türkiye'nin lojistik köy kurma potansiyelini ortaya koymak ve araştırmacılara ve lojistik köy kurulması konusunda yetkili mercilere stratejik bir yol haritası sunmaktır. Çalışmada, literatürde ele alınan araştırmaların incelenmesi sonucunda tespit edilen boşluklar giderilerek literatüre üç seviye katkı sunulmuştur. İlk olarak, bu çalışma Türkiye'nin coğrafi olarak bütününü analiz eden ilk çalışmadır. İkinci olarak, yer seçimi probleminde dikkate alınan bütün kriterlerin nicel belirlendiği ve gerçek verilerin kullanılarak farklı senaryolar altında çözümlerin değişkenliğinin incelendiği ilk çalışmadır. Ayrıca, değerlendirme kriterleri arasında kalkınmanın dikkate alınması da bu çalışmanın diğer bir katkısıdır. Böylece, çalışma sonucunda elde edilen çıktılar karar vericilerin bilgi ve tecrübelerine göre nihai olarak doğru bir karar vermesi için lojistik köy yer seçimi konusunda stratejik bir yol haritası sunmaktadır.

Çalışmada Türkiye'nin 81 ili TÜİK'in İstatistiki Bölge Birimleri Sınıflandırmasına (İBBS) göre Düzey 2 bazında 26 bölgeye ayrılmış ve bu bölgeler analiz edilmiştir. Çalışmada dört ana kriter (nitelikli işgücü, ulaşım altyapısı, ekonomik 
ve kalkınma) altında 16 alt kriter dikkate alınmıştır. Bu kriterlerin değerlerine TÜİK ve TCDD gibi Türkiye'nin kamu ve saygın özel kuruluşlarının veri tabanlarından erişilmiştir. Ele alınan nicel verilerin değerleri 2018 yılına aittir. Ana kriterlere farklı önem seviyelerinin atandığı 24 farklı senaryo için Türkiye'nin 26 bölgesi çok kriterleri karar verme tekniklerinden PROMETHEE II yöntemi kullanılarak analiz edilmiştir. Bütün senaryolarda Türkiye'nin en büyük potansiyeli sahip bölgesi TR10 bölgesi (İstanbul) çıkmıştır. İstanbul'un diğer bölgeler üzerindeki üstünlüğünün analiz içerisinde sapmalara neden olmaması için listeden çıkarılıp yapılan analiz sonucunda potansiyeli yüksek olan bölgeler belirlenmiştir. Kriterlerin farklı önem seviyelerinde elde edilen ilk 5 bölgeler incelenmiştir. Sonuç olarak nitelikli işgücü, ulaşım altyapısı ve ekonomik kriterlerin daha önemli olduğu durumlarda lojistik köy kurulması gereken bölgeler benzer çıkmıştır. Bu bölgeler, TR51 (Ankara), TR 42 (İzmit, Sakarya, Düzce, Bolu, Yalova), TR31 (İzmir), TR41 ( Bursa, Eskişehir, Bilecik) ve TR90 (Trabzon, Ordu, Giresun, Rize, Artvin, Gümüşhane), TR 32 (Aydın, Denizli, Muğla) bölgeleridir. Bu bölgelerden TR90 hariç diğerlerinde halihazırda tamamlanmış ya da projesi devam etmekte olan lojistik köyler bulunmaktadır. TR90 bölgesinin yakınındaki TR83 bölgesinde Samsun'da Gelemen lojistik köyü bulunmaktadir.

Daha önce yapılmış birden çok ili kapsayan çalışmaların sonuçları ile elde ettiğimiz sonuçları karşılaştırdığımızda sonuçların birbirini destekler nitelikte olduğunu söyleyebiliriz. Örneğin, Elgün ve Aşıkoğlu (2016) çalışmasında Bursa, Bilecik, Eskişehir, Afyon, Kütahya, Konya ve Mersin olmak üzere 7 şehri değerlendirmiştir ve lojistik köy için en uygun ilk 3 şehri Mersin, Konya ve Bilecik olarak sıralamıştır. Bizim çalışmamızda da işgücü, ulaşım ve ekonomik kriterlerin diğer kriterlere göre nispeten daha önemli olduğu durumlarda Bilecik'in içinde bulunduğu TR41 bölgesi sıralamada ilk 5 içinde yer almaktadır. Bilecik’te inşaat aşamasında olan Bozüyük lojistik köyü bulunmaktadır. Mersin ilinin içinde bulunduğu TR62 bölgesi ve Konya ilinin içinde bulunduğu TR52 bölgesi bizim çalışmamızda herhangi bir senaryo altında ilk 5 bölge içinde yer almamasına rağmen her iki şehirde de inşaat veya proje aşamasında olan lojistik köyler bulunmaktadır. Önder ve Yıldırım (2014) Türkiye'de hâlihazırda bir lojistik köyü ya da lojistik köy projesi olan 11 şehri incelemiş ve bunlar arasında Samsun, Eskişehir ve İzmit'i lojistik köy potansiyeli sıralamasında ilk 3 şehir olarak önermiştir. Bu çalışmada ise işgücü, ulaşım ve ekonomik kriterlerin önemli olduğu durumlarda Eskişehir'in içinde bulunduğu TR41 ve İzmit'in içinde bulunduğu TR42 bölgesi potansiyeli yüksek olan ilk 5 bölge içinde yer almaktadır ve bu iki şehirde Hasanbey (Eskişehir) ve Köseköy (İzmit) lojistik köyleri bulunmaktadır. Hamzaçebi vd. (2016) sadece Karadeniz bölgesinde yer alan 18 şehri değerlendirmiştir ve Samsun, Trabzon ve Zonguldak şehirlerinin lojistik köy kurulması açısından en uygun ilk 3 şehir olduğu önerilmiştir. Bu çalışmanın sonuçlarına göre Trabzon'un içinde bulunduğu TR90 bölgesi işgücü ve ulaşım kriterlerinin önemli olduğu senaryolarda ilk 5 bölge içinde yer almasına rağmen yakın bir bölge olan Samsun ve Zonguldak'ın yer aldıkları sırasıyla TR83 ve TR81 bölgeleri ilk 5'te yer almamaktadır. Ancak, Samsun'un hemen hemen bütün senaryolarda ilk 10'da çıktığı görülmektedir (bakınız Tablo 9). Ek olarak, herhangi bir lojistik köye ya da kurulum projesine sahip olmayan Trabzon ili Karadeniz ve Akpınar (2011)'a göre de lojistik köy kurulumu açısından potansiyeli yüksek bir şehir olarak değerlendirilmiştir.

Kalkınmanın en önemli görüldüğü senaryolarda beklenildiği üzere Doğu Anadolu Bölgesinde yer alan bölgeler sıralamanın ilk basamaklarında yer almıştır. İlk iki sırada yer alan bölgelerde devletin Kars ve Tatvan lojistik köyü projeleri bulunmaktadır. Altıncı sırada yer alan TRC3 bölgesinde inşaat aşamasında olan Mardin Lojistik köyü ve proje aşamasında olan Şırnak’taki Habur Lojistik Köyü bulunmaktadır. Bu sonuçlar ile TCDD yetkiliklerinin kararları arasında bir uyum olduğunu göstermektedir. Genel olarak çalışmanın sonuçları ile literatürdeki bazı çalışmaların ve uygulamadaki kararların arasında uyum görülmektedir. Bundan dolayı, Tablo 9'da detaylı bir şekilde sunulmuş sonuçların karar vericilere nihai karar verme öncesi önemli bilgiler sunduğu görülmüştür.

Karar vericiler bu bilgileri dikkate alırken bu çalışmanın kısıtlarını göz önünde bulundurmaları stratejik önem taşıyan yer seçimi kararı için önemlidir. İlk olarak, bu çalışmanın sonuçları Türkiye'yi kapsayan 26 bölge için sunulmuş ve bazı karar vericilerin önem verebileceği bazı nitel kriterler dikkate alınmamıştır. Örneğin, devletin ticaret ve yatırım politikaları veya dış politika stratejileri ile ilgili gelişmeler nihai kararı vermede çok etkili olabilir. Ayrıca, bölgeler içerisinde birden fazla şehir olduğu için hangi şehire ve o şehirde nereye kurulacağı ise nihai karar aşamasında belirlenecektir. Bu çalışmada yer almayan arazinin büyüklüğü, genişleme olanakları, devlet arazisi değilse arazi maliyetleri, arazinin uygunluğu ve altyapısı gibi bir çok kriter de son karar aşamasında dikkate alınması gerekecektir. Bu çalışma belirlenen kriter ve senaryolara göre her bir bölgenin mukayeseli olarak lojistik köy kurulma potansiyellerini göstermekte olup birden fazla lojistik köy kurulması durumunda bunların komşu bölgeler ile arasındaki ilişkileri dikkate almamaktadır. Kurulu olan ve kurulacak lojistik köylerin hem birbirleri hem de bütün bölgeler ile arasındaki ilişkinin dikkate alındığı (hub ve spoke) çok tesisli yer seçimi problemi ele alınıp hangi lojistik köyün hangi bölgelere hizmet verebileceği tespit edilebilir. 
Demirkıran, Y., Öztürkoğlu, Ö. / Journal of Yasar University, 2020, 15/58, 347-367

\section{KAYNAKLAR}

YÖK, (2018), Yüksek öğretim kurumu: https://istatistik.yok.gov.tr/, erişim tarihi 20.10.2018

Arikan, A. (2012), Freight villages and an application. Yükseklisans tezi. İstanbul: Bahçeşehir University.

Artan, G., Usta, G., ve Özmen, E. Hürriyet Gazetesi, (2018), http://www.hurriyet.com.tr/ekonomi/cin-ticaret-savasindangalip-cikmak-icin-turkiyeye-daha-cok-yatirim-yapacak-40974089, erişim tarihi: 02.10.2018.

Atalay, Ö., Karakaş, A. ve Akça, M. (2017), Türkiye'de lojistik merkezi yeri seçiminde kriterlerin AHP ile ağırlıklandırılması: Kars ili üzerine bir analiz. Atatürk Üniversitesi İktisadi ve İdari Bilimler Dergisi, 31(3), 607626.

Baki, R. (2018), Avrupa birliği ülkeleri ile Türkiye'deki lojistik köy uygulamaları ve uygun kuruluş yer seçimi. Adnan Menderes Üniversitesi, Sosyal Bilimler Enstitüsü Dergisi, 148-162.

Ballis, A., Mavrotas, G. (2007), Freight village design using the multicriteria method promethee. Operational Research. An International Journal, Vol.7(2), 213-232.

Baydar, A. M., Süral, H., ve Çelik, M. (2017), Freight villages: A literature review from the sustainability and societal equity perspective. Journal of cleaner production, 167, 1208-1221.

Brans, J. P. (1982), L'ingenierie de la decision, l'laboration d'instruments d'aidea la decision. Colloque sur l'Aidea la Decision. Faculte des Sciences de l'Administration, Universite Laval.

Brans, J. P., Vincke, P. H. (1985), Preference ranking organisation method. Management Science, Vol.31(6), 647-656. doi:doi.org/10.1287/mnsc.31.6.647

Bodaubayeva, G. (2015), Formation of industrial and logistic parks in Kazakhstan. 4th International Conference on Advanced Logistics and Transport (ICALT),41-46, IEEE.

Calis, A., Gencer, C., (2014), Historical Development ofWorldwide Freight Villages and Freight Villages in Turkey. CIE44 \& IMSS'14 Proceedings, Istanbul, Turkey.

Can, A. M. (2012), Selection the location of freight village in Samsun with Multi-Criteria Decision Making. Yükseklisans tezi. Kayseri: Erciyes University.

Chen, K.H., Liao, C.N., ve Wu, L.C. (2014), A selection model to logistic centers based on TOPSIS and MCGP methods: The case of airline industry. Journal of Applied Mathematics, 2014, 1-10. doi:http://dx.doi.org/10.1155/2014/470128

Chen, Y., Lili, Q. (2006), Evaluating the selection of logistics centre location using fuzzy MCDM model based on entropy weight. 6th World Congress on Intelligent Control and Automation. 2. Dalian: IEEE.

Cristea, M., Cristea, C. (2016), A multicriteria decision-making approach used for the selection of a logistics center location. Journal of Management and Technological Engineering, 1(1), 1-6. doi:10.15660/AUOFMTE.20161.3202

Demiroğlu, Ş., Eleren, A. (2014), Küresel lojistik köyleri ve Türkiye'de kurulması planlanan lojistik köy bölgelerinin ÇKKV yöntemleriyle belirlenmesi. Dumlupinar University Journal of Social Sciences, No.42, 189-242.

Dünya Bankası (2019), https://lpi.worldbank.org/international/aggregated-ranking erişim tarihi: 20.12.2019.

Elgün, M. N., Aşıkoğlu, N. O. (2016), Lojistik köy kuruluş yeri seçiminde TOPSIS yöntemiyle merkezlerin değerlendirilmesi. Afyon Kocatepe Üniversitesi İktisadi ve İdari Bilimler Fakültesi Dergisi, 18(1).

Erkayman, B., Gündoğar, E., Gökay, A., ve Ipek, M. (2011), A Fuzzy topsis approach for logistics senter. Journal of business case studies, 7(3), 49-55.

Eryürük, S. H., Kalaoğlu, F., ve Baskak, M. (2011), A Site Selection Model For Establishing A Clothing Logistics Center. Journal of Textile \& Apparel/Tekstil ve Konfeksiyon, 22(1), 40-47.

Europlatforms Corporate Presentation (2015), http://www.europlatforms.eu/wp-content/uploads/2016/01/CorporatePresentation-2015-Europlatforms-Final_20151229.pdf, erişim tarihi: 25.12.2019.

Fagaraşan, M., Cristea, C. (2015), Logistic center location: selection using multicriteria decision making. Proceedings of the Annual Sessions of Scientific Papers, 193-198.

Ghoseiri, K., Lessan, J. (2008), Location Selection for Logistic Centers using a Two- Step Fuzzy-AHP and ELECTRE Method. 9th Asia Pacific Industrial Engineering \& Management Systems Conference, 434-440, Bali.

Görgülü, H. (2012), Logistic villages and Konya application. Yükseklisans tezi. İstanbul: Bahçeşehir University.

Habertürk (2019), https://www.haberturk.com/marmaray-ile-cin-den-avrupa-ya-2537828-ekonomi, 24.12.2019, erişim tarihi: 24.12.2019.

Hamzaçebi, C., Imamoğlu, G., ve Alçı, A. (2016), Selection of Logistics Center Location with MOORA Method for Black Sea Region of Turkey. Journal of Economics Bibliography, 3(1), 74-82.

Higgins, C. D., Ferguson, M., ve Kanaroglou, P. S. (2012), Varieties of logistics centers: Developing standardized typology and hierarchy. Transportation Research Record, 2288(1), 9-18.

Invest in Turkey, (2018), http://www.invest.gov.tr/tr-TR/investmentguide/investorsguide/Pages/Incentives.aspx ,erişim tarihi: 10.10 .2018$.

Karadeniz, V., Akpinar, E. (2011), Türkiye'de lojistik köy uygulamaları ve yeni bir lojistik köy önerisi. Marmara Coğrafya Dergisi, (23), 49-71.

Kayikçı, Y. (2010), A conceptual model for intermodal freight logistics centre location decisions. The Sixth International Conference on City Logistics. No.2, 6297-6311. Graz: Procedia Social and Behavioral Sciences. 
Küçük, O., Yeşilyurt, E., ve Kartal, Ö. (2017), Lojistik köy performans faktörlerinin önem düzeyinin belirlenmesi: Kastamonu örneği. The International New Issues In Social Sciences, 4(4), 37-42.

Li, Y., Liu, X., ve Chen, Y. (2011), Selection of logistics center location using Axiomatic Fuzzy Set and TOPSIS methodology in logistics management. Expert Systems with Applications, 36(8), 7901-7908.

Oláh, J., Nestler, S., Nobel, T., ve Popp, J. (2018), Ranking of dry ports in Europe-Benchmarking. Periodica Polytechnica Transportation Engineering, 46(2), 95-100.

Önden, I., Acar, A. Z., ve Eldemir, F. (2018), Evaluation of the logistics center locations using a multi-criteria spatial approach. Transport, Vol.33(2), 322-334. doi:doi:10.3846/16484142.2016.1186113

Önden, İ., Eldemir, F., ve Çanc1, M. (2015), Logistics center concept and location decision criteria. Sigma Mühendislik ve Fen Bilimleri Dergisi, Vol.33(3), 325-340.

Önder, E., Yildirim, B. (2014), VIKOR Method for Ranking Logistic Villages In Turkey. Journal of Management and Economic Research, 12(23), 293-314.

Özceylan, E., Erbaş, M., Tolon, M., Kabak, M., ve Durğut, T. (2016), Evaluation of freight villages: A GIS-based multicriteria decision analysis. Computers in Industry, (76), $38-52$. doi:http://dx.doi.org/10.1016/j.compind.2015.12.003

Regmi, M., Hanaoka, S. (2013), Location analysis of logistics centres in Laos. International Journal of Logistics Research and Applications, 16(3), 227-242.

Resmi gazete, (2002), http://www.resmigazete.gov.tr/eskiler/2002/09/20020922.htm\#3, erişim tarihi: 10.10.2018.

Rimienė, K., ve Grundey, D. (2007), Logistics centre concept through evolution and definition. Inžinerine ekonomika, (4), 87-95.

Stevic, Z., Veskovic, S., Vasilyevic, M., ve Tepic, G. (2015), The Selection of The Logistics Center Location Using AHP Method. 2nd International Logistics Congress, 86-91, Belgrade.

Tanyaş, M., Bamyacı, M. (2009), Organize Lojistik Bölgesi Yer Seçimi Problemi için Bir Çok Ölçütlü Karar Verme Modeli: AHP-SAW. Mersin Sempozyumu. Mersin.

The world bank, (2018), https://lpi.worldbank.org/international/global, erişim tarihi:15.10.2018.

T.C. Ticaret Bakanlığı, (2019). Ekonomik https://ticaret.gov.tr/data/5b90d20a13b8760beca887fa/Ekonomik_Gorunum_Mart.pdf, $\quad$ erişim tarihi: 20.12.2019.

TCDD (2019), http://www.tcdd.gov.tr/content/33, erişim tarihi: erişim tarihi 23.12.2019.

Tomić, V., Marinkovic, D., ve Marinkovic, D. (2014), The selection of logistic centers location using multi-criteria comparison: Case Study of the Balkan Peninsula. Acta Polytechnica Hungarica, 11(10), 97-113.

TÜİK. (2015). 10.11.2018 tarihinde http://www.tuik.gov.tr/PreTablo.do?alt_id=1106 adresinden alındı

TÜIK, (2019), http://www.tuik.gov.tr/UstMenu.do?metod=temelist, erişim tarihi: 20.12.2019.

TLMP Yönetici özeti, (2019), https://ddgm.uab.gov.tr/uploads/pages/istatistikler-ve-raporlar/turkiye-lojistik-masterplani-yonetici-ozeti-2019.pdf, erişim tarihi: 25.12.2019.

Uyanik, C. (2016), An integrated DEMATEL-Intuitionistic Fuzzy TOPSIS methodology for logistics centers location selection. Yükseklisans tezi. Marmara University.

Uyanik, C., Tuzkaya, G., ve Oğuztimur, Ş. (2018), A literature survey on logistics centers' location selection problem. Sigma, 36(1), 141-160.

Uysal, T., Yavuz, K. (2014), Selection of Logistics Centre Location via ELECTRE Method: A Case Study in Turkey. 9th Asia Pacific Industrial Engineering \& Management Systems Conference. Bali.

Wang, S., Liu, P. (2007), The evaluation study on location selection of logistics center based on fuzzy AHP and TOPSIS. Wireless Communications, Networking and Mobile Computing, 3779-3782. International Conference on, IEEE.

Yang, C., Taudes, A., ve Dong, G. (2017), Efficiency analysis of European Freight Villages: three peers for benchmarking. Central European Journal of Operations Research, 25(1), 91-122.

Yangınlar, G. (2019). Uluslararasi ticaretin gelişmesinde lojistik köylerin önemi. In Durmaz, Y., Gün, S. (Eds.), Pazarlama ve işletme araştırmaları (51-75). İksad publishing house, Ankara.

Yildirim, B., Önder, E. (2014), Evaluating potential freight villages in Istanbul using multi criteria decision making techniques. Journal of Logistics Management, 3(1), 1-10.

Zak, J., Weglinski, S. (2014), The selection of the logistics center location based on MCDM/A methodology. Transportation Research Procedia, (3), 555-564.

Zalluhoğlu, E. A., Aracioğlu, B., ve Bozkurt, S. (2014), Lojistik Köy Kurulumunun Lojistik Hizmet Sağlayıcılar Açısından Değerlendirilmesi: İzmir Örneği. Ege Stratejik Araştırmalar Dergisi, 5(2), 81-103. 
Demirkıran, Y., Öztürkoğlu, Ö. / Journal of Yasar University, 2020, 15/58, 347-367

Tablo 6. Kriter Ağırlıkları

\begin{tabular}{|c|c|c|c|c|c|c|c|c|c|c|c|c|c|c|c|c|c|c|c|c|}
\hline & & & & & \multicolumn{4}{|c|}{ Nitelikli işgücü } & \multicolumn{5}{|c|}{ Ulaşım altyapısı } & \multicolumn{4}{|c|}{ Ekonomik } & \multicolumn{3}{|c|}{ Kalkınma } \\
\hline & & & & & $\begin{array}{c}\text { Ögre } \\
\text { nci } \\
\text { sayls } \\
\quad l\end{array}$ & $\begin{array}{c}\text { Akademi } \\
\text { syen } \\
\text { sayıs }\end{array}$ & $\begin{array}{c}\text { Lise } \\
\text { Mezu } \\
\text { nu } \\
\text { Çalıs } \\
\text { an } \\
\text { Sayls } \\
\quad l\end{array}$ & $\begin{array}{l}\text { Yükseköğr } \\
\text { etim } \\
\text { mezunu } \\
\text { çalışan } \\
\text { sayısı }\end{array}$ & $\begin{array}{l}\text { Hava } \\
\text { liman } \\
\quad l \\
\text { saylsl }\end{array}$ & $\begin{array}{l}\text { Lima } \\
n \\
\text { başka } \\
\text { nlığ } \\
\text { sayısı }\end{array}$ & $\begin{array}{c}\text { Karay } \\
\text { olu } \\
u z u n l \\
u \check{g u}\end{array}$ & $\begin{array}{c}\text { Demir } \\
\text { yolu } \\
u z u n l \\
\text { uğu }\end{array}$ & $\begin{array}{l}\text { Moto } \\
\text { rlu } \\
\text { taşıt } \\
\text { saylsl }\end{array}$ & $\begin{array}{l}\text { Dlş } \\
\text { ticar } \\
\text { et } \\
\text { gelirl } \\
\text { eri }\end{array}$ & $\begin{array}{l}\text { Giriş } \\
\quad \text { im } \\
\text { sayls } \\
\quad l\end{array}$ & $\begin{array}{l}\text { Uçak } \\
\text { sefer } \\
\text { saylsl }\end{array}$ & $\begin{array}{c}\text { Sinı } \\
r \\
\text { kapı } \\
\text { larl } \\
\text { na } \\
\text { olan } \\
\text { uza }\end{array}$ & 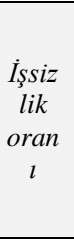 & $\begin{array}{c}\text { Teşv } \\
i k \\
\text { bölg } \\
\text { esi }\end{array}$ & $\begin{array}{c}\text { Yaşa } \\
m \\
\text { ende } \\
\text { ksi }\end{array}$ \\
\hline \multicolumn{5}{|c|}{ Ana Kriter Ağırlıkları } & 0,25 & 0,25 & 0,25 & 0,25 & 0,20 & 0,20 & 0,20 & 0,20 & 0,20 & 0,25 & 0,25 & 0,25 & 0,25 & 0,33 & 0,33 & 0,33 \\
\hline $\begin{array}{c}\text { Sena } \\
\text { ryo }\end{array}$ & $\begin{array}{l}N . \dot{I} s ̧ \\
\text { gücü }\end{array}$ & $\begin{array}{l}\text { Ulaşı } \\
m A .\end{array}$ & $\begin{array}{c}\text { Ekono } \\
\text { mik }\end{array}$ & $\begin{array}{c}\text { Kalkı } \\
n m a\end{array}$ & \multicolumn{16}{|c|}{ Alt Kriter Ağırlıkları } \\
\hline 1 & 0,1 & 0,2 & 0,3 & 0,4 & 0,03 & 0,03 & 0,03 & 0,03 & 0,04 & 0,04 & 0,04 & 0,04 & 0,04 & 0,08 & 0,08 & 0,08 & 0,08 & 0,13 & 0,13 & 0,13 \\
\hline 2 & 0,1 & 0,2 & 0,4 & 0,3 & 0,03 & 0,03 & & 0,03 & 0,04 & 0,04 & 0,04 & 0,04 & 0,04 & 0,10 & & & 0,10 & 0,10 & 0,10 & 0,10 \\
\hline 3 & 0,1 & 0,3 & 0,2 & & 03 & 0,03 & & & 0,06 & 0,06 & 0,06 & 0,06 & 0,06 & 0,05 & & & 0,05 & 0,13 & 0,13 & \\
\hline 4 & 0,1 & 0,3 & 0,4 & 0,2 & 0,03 & 0,03 & 0,03 & 0,03 & 0,06 & 0,06 & 0,06 & 0,06 & 0,06 & 0,10 & 0,10 & 0,10 & 0,10 & 0,07 & 0,07 & 0,07 \\
\hline 5 & 0,1 & 0,4 & 0,2 & 0,3 & 0,03 & 0,03 & 0,03 & 0,03 & 0,08 & 0,08 & 0,08 & 0,08 & 0,08 & 0,05 & 0,05 & 0,05 & 0,05 & 0,10 & 0,10 & 0,10 \\
\hline 6 & 0,1 & 0,4 & 0,3 & 0,2 & 0,03 & 0,03 & 0,03 & 0,03 & 0,08 & 0,08 & 0,08 & 0,08 & 0,08 & 0,08 & 0,08 & 0,08 & 0,08 & 0,07 & 0,07 & 0,07 \\
\hline 7 & 0,2 & 0,1 & 0,3 & 0,4 & 0,05 & 0,05 & 0,05 & 0,05 & 0,02 & 0,02 & 0,02 & 0,02 & 0,02 & 0,08 & 0,08 & 0,08 & 0,08 & 0,13 & 0,13 & 0,13 \\
\hline 8 & 0,2 & 0,1 & 0,4 & 0,3 & 0,05 & 0,05 & 0,05 & 0,05 & 0,02 & 0,02 & 0,02 & 0,02 & 0,02 & 0,10 & 0,10 & 0,10 & 0,10 & 0,10 & 0,10 & 0,10 \\
\hline 9 & 0,2 & 0,3 & 0,1 & 0,4 & 0,05 & 0,05 & 0,05 & 0,05 & 0,06 & 0,06 & 0,06 & 0,06 & 0,06 & 0,03 & 0,03 & 0,03 & 0,03 & 0,13 & 0,13 & 0,13 \\
\hline 10 & 0,2 & 0,3 & 0,4 & 0,1 & 0,05 & 0,05 & 0,05 & 0,05 & 0,06 & 0,06 & 0,06 & 0,06 & 0,06 & 0,10 & 0,10 & 0,10 & 0,10 & 0,03 & 0,03 & 0,03 \\
\hline 11 & 0,2 & 0,4 & 0,1 & 0,3 & 0,05 & 0,05 & 0,05 & 0,05 & 0,08 & 0,08 & 0,08 & 0,08 & 0,08 & 0,03 & 0,03 & 0,03 & 0,03 & 0,10 & 0,10 & 0,10 \\
\hline 12 & 0,2 & 0,4 & 0,3 & 0,1 & 0,05 & 0,05 & 0,05 & 0,05 & 0,08 & 0,08 & 0,08 & 0,08 & 0,08 & 0,08 & 0,08 & 0,08 & 0,08 & 0,03 & 0,03 & 0,03 \\
\hline 13 & 0,3 & 0,1 & 0,2 & 0,4 & 0,08 & 0,08 & 0,08 & 0,08 & 0,02 & 0,02 & 0,02 & 0,02 & 0,02 & 0,05 & 0,05 & 0,05 & 0,05 & 0,13 & 0,13 & 0,13 \\
\hline 14 & 0,3 & 0,1 & 0,4 & 0,2 & 0,08 & 0,08 & 0,08 & 0,08 & 0,02 & 0,02 & 0,02 & 0,02 & 0,02 & 0,10 & 0,10 & 0,10 & 0,10 & 0,07 & 0,07 & 0,07 \\
\hline 15 & 0,3 & 0,2 & 0,1 & 0,4 & 0,08 & 0,08 & 0,08 & 0,08 & 0,04 & 0,04 & 0,04 & 0,04 & 0,04 & 0,03 & 0,03 & 0,03 & 0,03 & 0,13 & 0,13 & 0,13 \\
\hline 16 & 0,3 & 0,2 & 0,4 & 0,1 & 0,08 & 0,08 & 0,08 & 0,08 & 0,04 & 0,04 & 0,04 & 0,04 & 0,04 & 0,10 & 0,10 & 0,10 & 0,10 & 0,03 & 0,03 & 0,03 \\
\hline 17 & 0,3 & 0,4 & 0,1 & 0,2 & 0,08 & 0,08 & 0,08 & 0,08 & 0,08 & 0,08 & 0,08 & 0,08 & 0,08 & 0,03 & 0,03 & 0,03 & 0,03 & 0,07 & 0,07 & 0,07 \\
\hline 18 & 0,3 & 0,4 & 0,2 & 0,1 & 0,08 & 0,08 & 0,08 & 0,08 & 0,08 & 0,08 & 0,08 & 0,08 & 0,08 & 0,05 & 0,05 & 0,05 & 0,05 & 0,03 & 0,03 & 0,03 \\
\hline 19 & 0,4 & 0,1 & 0,2 & 0,3 & 0,10 & 0,10 & 0,10 & 0,10 & 0,02 & 0,02 & 0,02 & 0,02 & 0,02 & 0,05 & 0,05 & 0,05 & 0,05 & 0,10 & 0,10 & 0,10 \\
\hline 20 & 0,4 & 0,1 & 0,3 & 0,2 & 0,10 & 0,10 & 0,10 & 0,10 & 0,02 & 0,02 & 0,02 & 0,02 & 0,02 & 0,08 & 0,08 & 0,08 & 0,08 & 0,07 & 0,07 & 0,07 \\
\hline 21 & 0,4 & 0,2 & 0,1 & 0,3 & 0,10 & 0,10 & 0,10 & 0,10 & 0,04 & 0,04 & 0,04 & 0,04 & 0,04 & 0,03 & 0,03 & 0,03 & 0,03 & 0,10 & 0,10 & 0,10 \\
\hline 22 & 0,4 & 0,2 & 0,3 & 0,1 & 0,10 & 0,10 & 0,10 & 0,10 & 0,04 & 0,04 & 0,04 & 0,04 & 0,04 & 0,08 & 0,08 & 0,08 & 0,08 & 0,03 & 0,03 & 0,03 \\
\hline 23 & 0,4 & 0,3 & 0,2 & 0,1 & 0,10 & 0,10 & 0,10 & 0,10 & 0,06 & 0,06 & 0,06 & 0,06 & 0,06 & 0,05 & 0,05 & 0,05 & 0,05 & 0,03 & 0,03 & 0,03 \\
\hline 24 & 0,4 & 0,3 & 0,1 & 0,2 & 0,10 & 0,10 & 0,10 & 0,10 & 0,06 & 0,06 & 0,06 & 0,06 & 0,06 & 0,03 & 0,03 & 0,03 & 0,03 & 0,07 & 0,07 & 0,07 \\
\hline
\end{tabular}


Demirkıran, Y., Öztürkoğlu, Ö. / Journal of Yasar University, 2020, 15/58, 347-367

Tablo 7.Visual Promethee Ekran Görüntüsü -Alternatiflerin Değerleri

\begin{tabular}{|c|c|c|c|c|c|c|c|c|c|c|c|c|c|c|c|c|c|}
\hline Searrit & & Obmes & Nods & Saltcien. & Iniveana. & movings & lons & Kandelit. & Demplije & Notakifapts & aqteles & ons & Setes & Sentele & Hedion & Inpidechk... & Thantridar \\
\hline be & & $\Rightarrow t$ & tet & $=\quad d$ & dat & dit & det & lndma & $\sin 2$ & 2. det & anores & det & aset & or & - & $-\quad \ldots$ & - \\
\hline asterione & & $\bullet$ & $\bullet$ & $\bullet$ & $\bullet$ & $\bullet$ & $\bullet$ & $\bullet$ & $\bullet$ & $\bullet$ & $\bullet$ & $\bullet$ & $\bullet$ & $\bullet$ & $\bullet$ & $\bullet$ & $\bullet$ \\
\hline \multicolumn{18}{|l|}{ medernacer } \\
\hline Antex & & res: & nas: & $\max$ & mox & $\operatorname{mas}$ & $\cos x$ & $=$ & $\max$ & nes: & $\operatorname{nox} x$ & ma & nax & $=m$ & $\operatorname{mox}$ & nox & $=$ \\
\hline mast & & 0.08 & $0.9 x$ & 0.03 & 8,007 & 0.94 & 0.04 & 0,04 & 0.04 & 0.94 & 0.00 & 8,00 & 0.80 & a.an & 0,0 & 8,13 & 0,22 \\
\hline Metrovet fin. & & in $x=$ & ther & trea & vew & Whate & thend & teope & verose & Nones: & ine & Inew & conson. & Counen & Gonem & Unuse & Nowe \\
\hline Threshalds & & onde & simbite & nonis: & severt & soditit & andisto & shosis. & sonste & moouste & sendine & sencite & conchits & tondite & tham & sodetr & sonderte \\
\hline 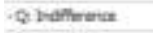 & & 20006 & nom & toon & 10060 & nia & no & no & $N$ & nis & 200000000 & 10000 & $\rightarrow$ & the & no & 0,000 & nie \\
\hline -9inetore & & 100000 & 10000 & $\$ 00000$ & 500000 & 2 & no & क्या & 9,81 & 15015 & 90000000 & $n 0000$ & nit & nie & nos & $\infty$ & Q.w7 \\
\hline -s: senasen & & No & nie & $n$ & $=\pi$ & nit & no & no & $N=$ & nis & no & no & 。 & o & $\infty$ & $\pi 0$ & nie \\
\hline \multicolumn{18}{|l|}{ Stentstios } \\
\hline \multicolumn{18}{|l|}{ tvatuationer. } \\
\hline TRis & $\square$ & $x \in 2563$ & $29 \sin$ & 149 & 1906 & 3 & 5 & 0,17 & 0,64 & 2993255 & Intsenen & 823372 & eans & 1150 & 129 & $1 / 200$ & Qiate \\
\hline Th5: & 口 & 100307 & 250 & int & wa & 3 & 3 & 0.31 & 9,00 & Dawo & xखmo & $m \infty 0$ & 20280 & 247 & as & 2,000 & $0.5 \pi$ \\
\hline 722 & $\square$ & $96 \leq 18$ & $2:$ & 138 & 150 & - & , & 0,25 & 0,01 & 202096 & 11802899 & 93600 & 2032 & 1.238 & 6,0 & 2,550 & 0,412 \\
\hline $\mathrm{nhih}$ & D & shin & ans & all & $\leq z$ & 2 & 5 & 0,10 & 0.05 & $313+1$ & 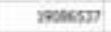 & रखख्या & และ & Ins? & 140 & $1 / 900$ & 0,000 \\
\hline$\pi / 2$ & $\square$ & 197216 & 5300 & 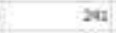 & 26 & $\cdot$ & ? & 0,00 & $0,0 t$ & saras & tsscosso & 17tse & 30050 & 1202 & 7,2 & 1,56e & 0,552 \\
\hline thes & 口 & sa1319 & $\omega 2$ & 23 & $a$ & 2 & 9 & $\theta=$ & 9,02 & $30 \times 92$ & बारका & ineas: & $21 \%$ & $12 \times 0$ & 6.2 & 2.,500 & 0,50 \\
\hline Tre-1 & 口 & $2050 \pi 7$ & $x+2$ & $\infty$ & $2 x$ & 3 & 2 & 0,65 & 0,03 & IX7425 & $22+50062$ & astess & Isees & 124: & 20 & 1,5ete & Q.813 \\
\hline 180 & $\square$ & 200004 & 7573 & 370 & 30 & 1 & 4 & a,51 & 0,02 & 288214 & 28067070 & 35060 & 3116 & 1003 & 10,8 & $2=0$ & 0.615 \\
\hline TR5: & 口 & 20040 & Las2: & जा & $\pi v i$ & 1 & 0 & 0,07 & 0,00 & $=209 \pi$ & 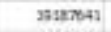 & $x \sin x$ & 208510 & 040 & 112 & 2000 & 0.038 \\
\hline TREF & 口 & 147275 & $3+1$ & 13 & 158 & 1 & 0 & 0,12 & $0.0 t$ & 253326 & 30.53544 & 257163 & at62 & 956 & 59 & 2,500 & 0,603 \\
\hline Thet & 口 & 19300 & เละ & 397 & 2is: & 3 & $s$ & 0,00 & 9,000 & Drass & savear & porar & 11749 & 1247 & 12,8 & 2000 & 0,002 \\
\hline TAL & $\square$ & 20917 & 4550 & 224 & 315 & 1 & 3 & 0,00 & 0,01 & 324136 & SEstros & 25510 & 45se & 941 & 18, 7 & 2,550 & 0,473 \\
\hline Res & D & $\operatorname{anco}$ & xot & $30 \%$ & in & 1 & 1 & 0,21 & 0,4 & 20065 & กxerey & mex & 19a1 & sx & 125 & 4.150 & 0,082 \\
\hline TR71 & $\square$ & 1110e? & 402 & 121 & 1002 & 1 & 0 & 0,2 & $0,0 t$ & 10334 & 200000 & setse & ast & ast & IL.4 & $<400$ & 0,565 \\
\hline$\pi / 2$ & 口 & aspo & 5240 & (15) & 173 & 2 & 9 & 0.3 & 9,02 & 21045 & 300000 & 50196 & 1360 & $m$ & i1.9 & $I_{1}, 450$ & 0.534 \\
\hline TRE1 & 口 & พ194 & 20501 & 23 & $\pi$ & t & 4 & $Q \mathrm{~m}=$ & 0,02 & nas & 206043 & 4ats: & 5 & 1001 & 72 & 1,500 & 0.581 \\
\hline tods & 口 & 5355 & 1894 & 56 & 53 & 1 & 5 & 0,53 & 0,01 & 9:13t & 60035 & $3+280$ & 1916 & 100+ & 46 & 4660 & 0.597 \\
\hline Ta3 & 口 & 21072 & 454] & Dמ & $19 \%$ & 2 & 3 & $0,4 \pi$ & $0,0 t$ & זמרי & Inson? & I117xa & 20000 & ตas & 27 & 4,000 & 0,980 \\
\hline TR20 & 口 & Sמล: & 6597 & 206 & 21? & 2 & 12 & 6,64 & 0,00 & 150312 & $2 \neq 0003$ & t12850 & 12300 & 858 & 36 & 4,230 & 0,580 \\
\hline Tha: & 口 & 3axep & 4077 & $\pi$ & $\pi$ & 2 & 0 & 0.22 & $0,0 t$ & 74485 & $\pi 054$ & 34151 & 12907 & $m$ & .5. & $5=00$ & 0,04 \\
\hline TRA? & $\square$ & 12230 & 2930 & Ei & e & 3 & 0 & 0,2 & 0,01 & $n 23$ & 3roves & atek & r452 & 803 & 8,3 & $E=060$ & 0,365 \\
\hline Tat & D & ตหมา & $4+4$ & 14 & 16 & 3 & 1 & 0.48 & $0 ., 23$ & 104055 & metia & Exe & ason & $n+$ & 3,0 & $4, \pi 00$ & $0,4 \pi$ \\
\hline TRe? & $\square$ & 43 & ant & st & $\pi$ & 2 & I & 0,24 & $0, \theta t$ & roors & 200000 & 5000 & 24e:4 & ans & 12,8 & E.40 & 0,36 \\
\hline TREI & 口 & avose & 3298 & 154 & 167 & 2 & 9 & $\Delta, 4 \pi$ & 9,02 & 17 mate & 1270 & 102003 & 19457 & 70 & 1S: & 4,500 & 0,415 \\
\hline $\mathbb{A C Z}$ & 口 & ssast & 2000 & เมี & Tab: & 2 & 0 & $a, 00$ & 0,01 & $1 \mathrm{~m}$ & steocos & mes & sastr & $\pi 2$ & 139 & $\$, 000$ & 0,381 \\
\hline tod & 口 & 30285 & 5050 & 91 & 101 & 1 & 0 & 0,35 & 0,01 & 90096 & $17 \rightarrow-02$ & $5 k<5$ & 104 & $\pi 4$ & 26.9 & 5,200 & thise \\
\hline
\end{tabular}


Demirkıran, Y., Öztürkoğlu, Ö. / Journal of Yasar University, 2020, 15/58, 347-367

Tablo 8. Türkiye'nin 26 Bölgesinin 24 Senaryo Altında Lojistik Köy Yeri Seçimi Açısından Sıralanması

\begin{tabular}{|c|c|c|c|c|c|c|c|c|c|c|c|c|c|c|c|c|c|c|c|c|c|c|c|c|}
\hline & & & & & & & & & & & & & yolar & & & & & & & & & & & \\
\hline Sira & S1 & $S 2$ & S3 & S4 & S5 & S6 & S7 & 58 & $S 9$ & $S 10$ & $S 11$ & $S 12$ & $S 13$ & S14 & $S 15$ & $S 16$ & S17 & $S 18$ & $S 19$ & $S 20$ & $S 21$ & $S 22$ & $S 23$ & $S 24$ \\
\hline 1 & TR10 & TR10 & TR10 & TR10 & TR10 & TR10 & TR10 & TR10 & TR10 & TR10 & TR10 & TR10 & TR10 & TR10 & TR10 & TR10 & TR10 & TR10 & TR10 & TR10 & TR10 & TR10 & TR10 & TR10 \\
\hline 2 & TRB2 & TRC1 & TRA2 & TR42 & TRB1 & TR41 & TRC2 & TRC2 & TRB1 & TR42 & TRB1 & TR42 & TRC2 & TR51 & TRA2 & TR51 & TR42 & TR42 & TR51 & TR51 & TR42 & TR51 & TR51 & TR42 \\
\hline 3 & TRA2 & TR42 & TRB1 & TR41 & TR90 & TR42 & TRB2 & TR51 & TRA2 & TR31 & TR90 & TR41 & TRB2 & TR42 & TRB2 & TR42 & TR41 & TR31 & TR42 & TR42 & TR51 & TR42 & TR42 & TR51 \\
\hline 4 & TRC1 & TR90 & TRC1 & TR31 & TR42 & TR31 & TRA2 & TR42 & TRC1 & TR41 & TR42 & TR31 & TRA2 & TR31 & TRB1 & TR31 & TR31 & TR41 & TR90 & TR31 & TR90 & TR31 & TR31 & TR90 \\
\hline 5 & TRC2 & TR41 & TRB2 & TR32 & TR41 & TR32 & TRC3 & TRC1 & TRB2 & TR51 & TR41 & TR32 & TRC3 & TR41 & TRC1 & TR41 & TR90 & TR51 & TRC1 & TR41 & TRB1 & TR41 & TR41 & TR41 \\
\hline 6 & TRB1 & TR31 & TR90 & TR90 & TRC1 & TR90 & TRC1 & TRB2 & TR90 & TR32 & TRC1 & TR51 & TRC1 & TR61 & TR90 & TR32 & TR32 & TR32 & TRC2 & TR90 & TRC1 & TR61 & TR32 & TR31 \\
\hline 7 & TRC3 & TRB1 & TRC2 & TR51 & TR32 & TRB1 & TRB1 & TR90 & TRC2 & TR61 & TR32 & TR61 & TRB1 & TR90 & TRC2 & TR61 & TR51 & TR90 & TRB2 & TR61 & TR33 & TR32 & TR61 & TR32 \\
\hline 8 & TR90 & TRC2 & TRC3 & TR61 & TR31 & TR33 & TR63 & TRA2 & TRC3 & TR33 & TR31 & TR90 & TR90 & TR32 & TRC3 & TR33 & TRB1 & TR61 & TRB1 & TR33 & TR41 & TR33 & TR90 & TR33 \\
\hline 9 & TR63 & TRB2 & TR83 & TR33 & TRA2 & TR61 & TR90 & TR63 & TR83 & TR90 & TR33 & TR33 & TR63 & TR33 & TR42 & TR90 & TR33 & TR33 & TR33 & TR32 & TR31 & TR90 & TR33 & TR61 \\
\hline 10 & TR83 & TRA2 & TR42 & TRC1 & TR33 & TRC1 & TR42 & TR31 & TR42 & TR83 & TR83 & TRB1 & TR51 & TRC1 & TR83 & TR62 & TR61 & TRB1 & TRA2 & TRC1 & TRA2 & TR83 & TRB1 & TRB1 \\
\hline 11 & TR42 & TR32 & TR33 & TRB1 & TR83 & TR83 & TR83 & TRC3 & TR33 & TR62 & TRA2 & TR83 & TR42 & TR62 & TR33 & TR83 & TR83 & TR83 & TR31 & TR83 & TRB2 & TR62 & TR83 & TR83 \\
\hline 12 & TR33 & TR51 & TR63 & TR83 & TRB2 & TR51 & TR51 & TRB1 & TR41 & TRB1 & TR61 & TR22 & TR83 & TR83 & TR63 & TR72 & TRC1 & TR22 & TR61 & TRB1 & TR61 & TR72 & TR72 & TRC1 \\
\hline 13 & TR41 & TR83 & TR41 & TR62 & TR61 & TR22 & TR62 & TR41 & TR32 & TRC1 & TRB2 & TRC1 & TR33 & TR63 & TR72 & TRB1 & TR72 & TRC1 & TR41 & TR62 & TR83 & TRB1 & TR62 & TR72 \\
\hline 14 & TR32 & TR33 & TR32 & TR72 & TR72 & TR62 & TR33 & TR33 & TR63 & TR22 & TR72 & TR62 & TR72 & TRB1 & TR51 & TRC1 & TR22 & TR72 & TR83 & TR72 & TR32 & TRC1 & TRC1 & TR62 \\
\hline 15 & TR62 & TR63 & TR31 & TRA2 & TR22 & TR72 & TR72 & TR32 & TR72 & TR72 & TR51 & TR72 & TRA1 & TRC2 & TR41 & TR22 & TR81 & TR62 & TRC3 & TR63 & TR72 & TR22 & TR22 & TRA2 \\
\hline 16 & TR31 & TR61 & TR72 & TR63 & TR62 & TRA2 & TR32 & TR61 & TR31 & TR81 & TR22 & TR81 & TR61 & TR72 & TR32 & TR63 & TRA2 & TR81 & TR63 & TRC2 & TRC2 & TR63 & TR81 & TR81 \\
\hline 17 & TR72 & TRC3 & TR62 & TR22 & TRC2 & TR81 & TRA1 & TR62 & TR61 & TR21 & TR81 & TR21 & TR62 & TRB2 & TR61 & TR21 & TR62 & TR21 & TR72 & TRB2 & TRC3 & TR21 & TR21 & TRB2 \\
\hline 18 & TR61 & TR62 & TR61 & TRB2 & TR81 & TRB2 & TR61 & TR83 & TR62 & TR63 & TR62 & TR82 & TR32 & TRA2 & TR31 & TR81 & TRB2 & TR82 & TR32 & TRA2 & TR63 & TR81 & TR63 & TR22 \\
\hline 19 & TR51 & TR72 & TR82 & TRC2 & TR63 & TR63 & TR41 & TR72 & TR82 & TR82 & TRC2 & TR63 & TR71 & TRC3 & TRA1 & TR52 & TR82 & TR63 & TR62 & TR71 & TR62 & TR52 & TR71 & TR63 \\
\hline 20 & TRA1 & TR22 & TR81 & TR81 & TR51 & TR82 & TR31 & TRA1 & TR81 & TRA2 & TR63 & TRA2 & TR41 & TR71 & TR62 & TR71 & TR63 & TRA2 & TR71 & TRC3 & TR71 & TR71 & TR82 & TR71 \\
\hline 21 & TR71 & TR71 & TR22 & TRC3 & TRC3 & TR21 & TR71 & TR71 & TR51 & TRB2 & TRC3 & TRB2 & TR31 & TRA1 & TR71 & TRC2 & TR21 & TR71 & TRA1 & TRA1 & TRA1 & TRB2 & TR52 & TR21 \\
\hline 22 & TR82 & TR82 & TRA1 & TR21 & TR82 & TRC2 & TR82 & TR82 & TRA1 & TR71 & TR82 & TR71 & TR82 & TR52 & TR81 & TRB2 & TR71 & TRB2 & TR81 & TR52 & TR81 & TRC2 & TRA2 & TRC2 \\
\hline 23 & TR81 & TRA1 & TR51 & TR82 & TR21 & TRC3 & TR81 & TR81 & TR71 & TR52 & TR21 & TR52 & TR81 & TR21 & TR82 & TRA2 & TRC2 & TR52 & TR52 & TR21 & TR82 & TRA2 & TRB2 & TR82 \\
\hline 24 & TR22 & TR81 & TR71 & TR71 & TR71 & TR71 & TR21 & TR21 & TR22 & TRC2 & TR71 & TRC2 & TR52 & TR81 & TR22 & TR82 & TRC3 & TRA1 & TR82 & TR81 & TR22 & TR82 & TRA1 & TRC3 \\
\hline 25 & TR21 & TR21 & TR21 & TRA1 & TRA1 & TRA1 & TR52 & TR52 & TR21 & TRC3 & TRA1 & TRC3 & TR21 & TR22 & TR21 & TRA1 & TRA1 & TRC2 & TR21 & TR22 & TR21 & TRA1 & TRC2 & TRA1 \\
\hline 26 & TR52 & TR52 & TR52 & TR52 & TR52 & TR52 & TR22 & TR22 & TR52 & TRA1 & TR52 & TRA1 & TR22 & TR82 & TR52 & TRC3 & TR52 & TRC3 & TR22 & TR82 & TR52 & TRC3 & TRC3 & TR52 \\
\hline
\end{tabular}


Demirkıran, Y., Öztürkoğlu, Ö. / Journal of Yasar University, 2020, 15/58, 347-367

Tablo 9. Türkiye'nin İstanbul Hariç 25 Bölgesinin 24 Senaryo Altında Lojistik Köy Yeri Seçimi Açısından Sıralanması

\begin{tabular}{|c|c|c|c|c|c|c|c|c|c|c|c|c|c|c|c|c|c|c|c|c|c|c|c|c|}
\hline \multirow[b]{2}{*}{ Sira } & \multicolumn{24}{|c|}{ Senaryolar } \\
\hline & $S 1$ & $S 2$ & $S 3$ & $S 4$ & S5 & S6 & $S 7$ & $S 8$ & $S 9$ & $S 10$ & $S 11$ & $S 12$ & $S 13$ & $S 14$ & S15 & $S 16$ & $S 17$ & $S 18$ & $S 19$ & $S 20$ & $S 21$ & $S 22$ & $S 23$ & $S 24$ \\
\hline 1 & TRB2 & TR42 & TRA2 & TR42 & TRB1 & TR41 & TRC2 & TR51 & TRB1 & TR42 & TRB1 & TR42 & TRC2 & TR51 & TRB2 & TR51 & TR42 & TR42 & TR51 & TR51 & TR51 & TR51 & TR51 & TR42 \\
\hline 2 & TRA2 & TRC1 & TRB1 & TR41 & TR41 & TR42 & TRB2 & TRC2 & TRA2 & TR31 & TR90 & TR41 & TRB2 & TR42 & TRA2 & TR42 & TR41 & TR41 & TR42 & TR42 & TR42 & TR42 & TR42 & TR51 \\
\hline 3 & TRC2 & TR41 & TRC1 & TR31 & TR42 & TR31 & TRA2 & TR42 & TRC1 & TR41 & TR42 & TR31 & TRA2 & TR31 & TRB1 & TR31 & TR31 & TR31 & TR90 & TR31 & TR90 & TR31 & TR31 & TR41 \\
\hline 4 & TRC1 & TR31 & TRB2 & TR32 & TR90 & TR32 & TRC3 & TRC1 & TRB2 & TR51 & TR41 & TR32 & TRC3 & TR41 & TRC1 & TR41 & TR90 & TR51 & TRC1 & TR41 & TRB1 & TR41 & TR41 & TR31 \\
\hline 5 & TRB1 & TR90 & TR90 & TR51 & TRC1 & TR90 & TRC1 & TRB2 & TR90 & TR32 & TRC1 & TR51 & TRC1 & TR61 & TR90 & TR32 & TR51 & TR32 & TRC2 & TR90 & TR33 & TR61 & TR32 & TR90 \\
\hline 6 & TRC3 & TRC2 & TRC2 & TR90 & TR31 & TRB1 & TR63 & TR90 & TRC2 & TR61 & TR31 & TR61 & TRB1 & TR90 & TRC2 & TR61 & TR32 & TR90 & TRB2 & TR61 & TRC1 & TR32 & TR61 & TR33 \\
\hline 7 & TR90 & TRB1 & TRC3 & TR33 & TR32 & TR33 & TRB1 & TR31 & TRC3 & TR33 & TR32 & TR33 & TR90 & TR32 & TRC3 & TR33 & TR33 & TR61 & TRB1 & TR33 & TR41 & TR33 & TR90 & TR32 \\
\hline 8 & TR63 & TRB2 & TR83 & TR61 & TR33 & TR61 & TR90 & TR63 & TR83 & TR90 & TR33 & TR90 & TR63 & TR33 & TR42 & TR90 & TRB1 & TR33 & TR33 & TR32 & TR31 & TR90 & TR33 & TRB1 \\
\hline 9 & TR83 & TR32 & TR42 & TRC1 & TR83 & TR51 & TR42 & TRA2 & TR42 & TR83 & TR83 & TRB1 & TR51 & TRC1 & TR83 & TR62 & TR61 & TRB1 & TR31 & TRC1 & TRB2 & TR83 & TR83 & TR61 \\
\hline 10 & TR42 & TRA2 & TR41 & TRB1 & TRA2 & TRC1 & TR83 & TR41 & TR33 & TR62 & TRA2 & TR83 & TR42 & TR62 & TR33 & TR83 & TR83 & TR83 & TRA2 & TR83 & TRA2 & TR62 & TRB1 & TR83 \\
\hline 11 & TR41 & TR51 & TR33 & TR83 & TRB2 & TR83 & TR51 & TRC3 & TR41 & TRB1 & TRB2 & TR22 & TR83 & TR83 & TR51 & TR72 & TRC1 & TR22 & TR41 & TRB1 & TR32 & TR72 & TR72 & TRC1 \\
\hline 12 & TR33 & TR33 & TR63 & TR62 & TR61 & TR62 & TR33 & TRB1 & TR32 & TRC1 & TR61 & TR62 & TR33 & TR63 & TR63 & TRB1 & TR72 & TR72 & TR61 & TR72 & TR90 & TRB1 & TR62 & TR72 \\
\hline 13 & TR32 & TR83 & TR32 & TR72 & TR72 & TR22 & TR62 & TR32 & TR63 & TR22 & TR51 & TRC1 & TR72 & TRC2 & TR72 & TRC1 & TR22 & TRC1 & TR83 & TR62 & TR61 & TRC1 & TRC1 & TR62 \\
\hline 14 & TR31 & TR63 & TR31 & TR63 & TR51 & TR72 & TR72 & TR33 & TR72 & TR72 & TR72 & TR72 & TRA1 & TRB1 & TR41 & TR22 & TR81 & TR62 & TRC3 & TR63 & TR72 & TR22 & TR22 & TRA2 \\
\hline 15 & TR62 & TR61 & TR72 & TRA2 & TR62 & TRA2 & TR41 & TR61 & TR31 & TR81 & TR81 & TR81 & TR61 & TR72 & TR32 & TR63 & TR62 & TR81 & TR63 & TRC2 & TRC2 & TR63 & TR81 & TR81 \\
\hline 16 & TR72 & TRC3 & TR62 & TR22 & TR22 & TR81 & TR32 & TR83 & TR61 & TR21 & TR22 & TR21 & TR41 & TRB2 & TR31 & TR21 & TRA2 & TR21 & TR72 & TRB2 & TR63 & TR21 & TR21 & TRB2 \\
\hline 17 & TR61 & TR62 & TR61 & TRB2 & TRC2 & TRB2 & TR31 & TR62 & TR62 & TR63 & TR62 & TR82 & TR62 & TRA2 & TR61 & TR81 & TRB2 & TR82 & TR32 & TRA2 & TRC3 & TR81 & TR63 & TR22 \\
\hline 18 & TR51 & TR72 & TR82 & TRC2 & TR81 & TR63 & TR61 & TR72 & TR51 & TR82 & TRC2 & TR63 & TR32 & TRC3 & TRA1 & TR52 & TR21 & TR63 & TR62 & TR71 & TR62 & TR52 & TR71 & TR63 \\
\hline 19 & TRA1 & TR71 & TR81 & TR81 & TR63 & TR82 & TRA1 & TRA1 & TR82 & TRA2 & TR63 & TRA2 & TR31 & TR71 & TR62 & TR71 & TR63 & TRA2 & TR71 & TRC3 & TR71 & TR71 & TR52 & TR71 \\
\hline 20 & TR71 & TR22 & TR51 & TRC3 & TRC3 & TR21 & TR71 & TR71 & TR81 & TRB2 & TRC3 & TRB2 & TR71 & TRA1 & TR71 & TRC2 & TR82 & TR71 & TRA1 & TRA1 & TRA1 & TRB2 & TR82 & TR21 \\
\hline 21 & TR82 & TR82 & TRA1 & TR21 & TR82 & TRC2 & TR82 & TR82 & TRA1 & TR71 & TR82 & TR71 & TR82 & TR52 & TR81 & TRB2 & TR71 & TRB2 & TR81 & TR52 & TR81 & TRC2 & TRA2 & TRC2 \\
\hline 22 & TR81 & TRA1 & TR22 & TR82 & TR21 & TRC3 & TR81 & TR81 & TR71 & TR52 & TR21 & TR52 & TR81 & TR21 & TR82 & TRA2 & TRC2 & TR52 & TR52 & TR21 & TR82 & TRA2 & TRB2 & TR82 \\
\hline 23 & TR22 & TR81 & TR71 & TR71 & TR71 & TR71 & TR21 & TR21 & TR22 & TRC2 & TR71 & TRC2 & TR52 & TR81 & TR22 & TR82 & TRC3 & TRA1 & TR82 & TR81 & TR21 & TRA1 & TRA1 & TRC3 \\
\hline 24 & TR21 & TR21 & TR21 & TRA1 & TRA1 & TRA1 & TR52 & TR52 & TR21 & TRC3 & TRA1 & TRC3 & TR21 & TR22 & TR21 & TRA1 & TRA1 & TRC2 & TR21 & TR22 & TR22 & TR82 & TRC2 & TRA1 \\
\hline 25 & TR52 & TR52 & TR52 & TR52 & TR52 & TR52 & TR22 & TR22 & TR52 & TRA1 & TR52 & TRA1 & TR22 & TR82 & TR52 & TRC3 & TR52 & TRC3 & TR22 & TR82 & TR52 & TRC3 & TRC3 & TR52 \\
\hline
\end{tabular}

